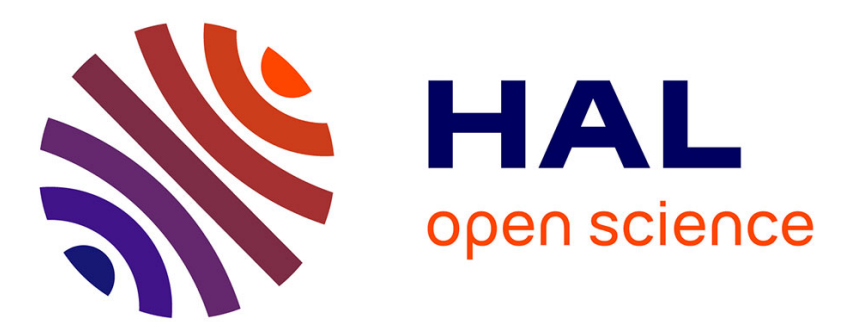

\title{
Entrainment of stratospheric air and Asian pollution by the convective boundary layer in the southwestern U.S.
}

A O Langford, R J Alvarez, Jérome Brioude, R Fine, M S Gustin, M y Lin, R D Marchbanks, R B Pierce, S P Sandberg, C J Senff, et al.

\section{- To cite this version:}

A O Langford, R J Alvarez, Jérome Brioude, R Fine, M S Gustin, et al.. Entrainment of stratospheric air and Asian pollution by the convective boundary layer in the southwestern U.S.. Journal of Geophysical Research: Atmospheres, 2017, 122, pp.1312 - 1337. 10.1002/2016jd025987 . hal-03135282

\section{HAL Id: hal-03135282 \\ https://hal.univ-reunion.fr/hal-03135282}

Submitted on 2 Sep 2021

HAL is a multi-disciplinary open access archive for the deposit and dissemination of scientific research documents, whether they are published or not. The documents may come from teaching and research institutions in France or abroad, or from public or private research centers.
L'archive ouverte pluridisciplinaire HAL, est destinée au dépôt et à la diffusion de documents scientifiques de niveau recherche, publiés ou non, émanant des établissements d'enseignement et de recherche français ou étrangers, des laboratoires publics ou privés.

$$
\text { Copyright }
$$




\section{Journal of Geophysical Research: Atmospheres}

\section{RESEARCH ARTICLE \\ 10.1002/2016JD025987 \\ Key Points: \\ - The deep convective boundary layers \\ Entrainment of stratospheric air and Asian pollution by the convective boundary layer in the southwestern U.S.} of the Southwestern U.S. increase entrainment of stratospheric air and transported pollution

- Stratospheric intrusions contribute to the springtime surface ozone maximum in the Southwestern U.S

- Stratospheric intrusions can cause exceedances of the National Ambient Air Quality Standard for ozone in the Southwestern U.S

Supporting Information:

- Supporting Information S1

Correspondence to:

A. O. Langford,

andrew.o.langford@noaa.gov

Citation:

Langford, A. O., et al. (2017), Entrainment of stratospheric air and Asian pollution by the convective boundary layer in the southwestern U.S. J. Geophys. Res. Atmos., 122, 1312-1337, doi:10.1002/2016JD025987.

Received 22 SEP 2016 Accepted 27 DEC 2016 Accepted article online 30 DEC 2016 Published online 25 JAN 2017

\author{
A. O. Langford ${ }^{1}$ (D, R. J. Alvarez II ${ }^{1}$, J. Brioude ${ }^{2,3}$, R. Fine ${ }^{4,5}$, M. S Gustin ${ }^{4}$, M. Y. Lin ${ }^{6,7}$, \\ R. D. Marchbanks ${ }^{1,2}$, R. B. Pierce ${ }^{8}$ ID, S. P. Sandberg ${ }^{1}$, C. J. Senff ${ }^{1,2}$, A. M. Weickmann ${ }^{1,2}$, and \\ E. J. Williams ${ }^{1}$ (iD
}

${ }^{1}$ NOAA Earth System Research Laboratory/Chemical Sciences Division, Colorado, Boulder, USA, ${ }^{2}$ Cooperative Institute for Research in the Environmental Sciences, University of Colorado Boulder, Colorado, Boulder, USA, ${ }^{3}$ Laboratoire de I'Atmosphere et des Cyclones, La Reunion, France, ${ }^{4}$ Department of Natural Resources and Environmental Science, University of Nevada, Reno, Reno, Nevada, USA, ${ }^{5}$ Present address, California Air Resources Board, Sacramento, California, USA, ${ }^{6}$ Atmospheric and Oceanic Sciences, Princeton University, Princeton, New Jersey, USA, ${ }^{7}$ NOAA Geophysical Fluid Dynamics Laboratory, Princeton, New Jersey, USA, ${ }^{8}$ NOAA/NESDIS Center for Satellite Applications and Research, Cooperative Institute for Meteorological Satellite Studies, Madison, Wisconsin, USA

Abstract A series of deep stratospheric intrusions in late May 2013 increased the daily maximum $8 \mathrm{~h}$ surface ozone $\left(\mathrm{O}_{3}\right)$ concentrations to more than 70 parts per billion by volume (ppbv) at rural and urban surface monitors in California and Nevada. This influx of ozone-rich lower stratospheric air and entrained Asian pollution persisted for more than 5 days and contributed to exceedances of the $20088 \mathrm{~h}$ national ambient air quality standard of 75 ppbv on 21 and 25 May in Clark County, NV. Exceedances would also have occurred on 22 and 23 May had the new standard of 70 ppbv been in effect. In this paper, we examine this episode using lidar measurements from a high-elevation site on Angel Peak, NV, and surface measurements from NOAA, the Clark County, Nevada Department of Air Quality, the Environmental Protection Agency Air Quality System, and the Nevada Rural Ozone Initiative. These measurements, together with analyses from the National Centers for Environmental Prediction/North American Regional Reanalysis; NOAA Geophysical Fluid Dynamics Laboratory AM3 model; NOAA National Environmental Satellite, Data, and Information Service Real-time Air Quality Modeling System; and FLEXPART models, show that the exceedances followed entrainment of $\sim 20$ to $40 \mathrm{ppbv}$ of lower stratospheric ozone mingled with another 0 to 10 ppbv of ozone transported from Asia by the unusually deep convective boundary layers above the Mojave desert. Our analysis suggests that this vigorous mixing can affect both high and low elevations and help explain the springtime ozone maximum in the southwestern U.S.

\section{Introduction}

There is compelling evidence that even moderate concentrations of ozone $\left(\mathrm{O}_{3}\right)$ can adversely affect human health and impair plant growth and productivity [U.S. Environmental Protection Agency, 2014]. The U.S. Environmental Protection Agency (EPA) accordingly set a national ambient air quality standard (NAAQS) for ozone in 1971 that has been periodically lowered as new data on the health impacts have become available. Much of the ozone near the surface is formed through photochemical reactions between nitrogen oxides $\left(\mathrm{NO}_{\mathrm{x}}\right.$ ) and volatile organic compounds (VOCs) of local or regional origin, but ozone is the only one of the six criteria pollutants regulated by the U.S. Clean Air Act (CAA) that also has significant background concentrations that remain beyond local control. The NAAQS has gradually approached these background concentrations with time, and the recent reduction [U.S. Environmental Protection Agency, 2015] in the NAAQS from 75 to 70 parts per billion by volume (ppbv) adds urgency to the need for better understanding of the processes that control ground-level background ozone in the United States [Cooper et al., 2015]. This is particularly true for the southwestern U.S. and Intermountain West, where surface ozone peaks in late May and early June with daily maximum $8 \mathrm{~h}$ average (MDA8) concentrations that approach and sometimes exceed the revised standard in both urban and rural areas [Fine et al., 2015a; Fiore et al., 2014; Gustin et al., 2015; Langford et al., 2012; Langford et al., 2015b; Lefohn et al., 2014; Lefohn et al., 2012; Lin et al., 2012a; Lin et al., 2012b; Zhang et al., 2014].

The springtime maximum in the Southwest occurs earlier than would be expected from photochemistry alone and is consistent with transport of naturally occurring ozone from the lower stratosphere [Johnson 

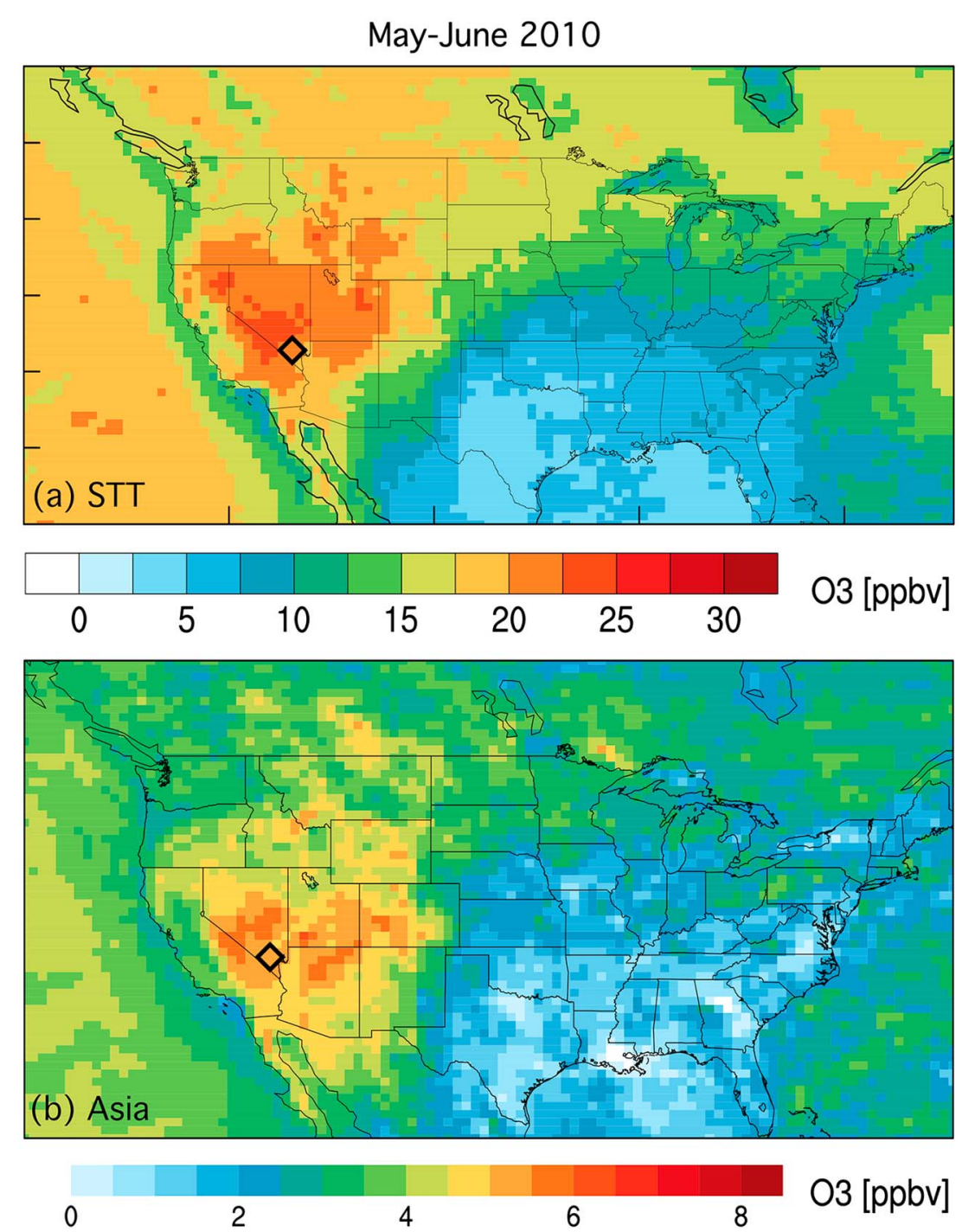

Figure 1. (a) Modeled contribution of stratospheric $\mathrm{O}_{3}$ to the monthly mean MDA8 surface concentrations in the continental United States during May-June 2010 from the NOAA GFDL AM3 model. (b) Corresponding contribution of transport from Asia. Note the different color scales. The diamonds show the location of Angel Peak.

and Viezee, 1981; Viezee et al., 1983] and, to a lesser degree, transport of ozone formed from anthropogenic precursors emitted in Asia [Jacob et al., 1999; Jaffe et al., 1999]. These two processes are strongly coupled during springtime when pollution transported across the Pacific by midlatitude cyclones can merge with upper tropospheric/lower stratospheric (UT/LS) air descending in tropopause folds [Cooper et al., 2004]. While rising Asian anthropogenic emissions contribute to western U.S. ozone trends [Lin et al., 2015b], the frequency of stratospheric intrusions plays a key role in the year-to-year variability of high-ozone events measured at western U.S. surface sites [Lin et al., 2015a] and can complicate the unambiguous attribution of ozone trends derived from sparse in situ sampling [Cooper et al., 2010]. This episodic transport can create localized spikes in surface ozone and increase background concentrations over large areas for several days.

Global models [Fiore et al., 2014] such as Goddard Earth Observing System-Chemistry model [Huang et al., 2015; Zhang et al., 2014] and the NOAA Geophysical Fluid Dynamics Laboratory (GFDL) Atmosphere Model version 3 (AM3) model [Lin et al., 2012a; Lin et al., 2012b] (Figure 1) suggest that stratospheric intrusions and mingled Asian pollution have a much greater impact on surface ozone in the southwestern U.S. and Intermountain West than in other regions of the country, a disparity that poses a problem for the U.S. Environmental Protection Agency (EPA), which is required by the CAA [U.S. Environmental Protection Agency, 1999] to apply the same air quality standards across the entire United States. Although EPA has 
regulatory mechanisms within the Clean Air Act designed to provide relief for high-background ozone (e.g., the Exceptional Events Rule, Section $182 \mathrm{~h}$ (rural transport areas), and Section 179B (international transport)), it has been proven challenging to implement these mechanisms because of the difficulty in quantifying stratosphere-to-troposphere transport (STT) and long-range transport compared to the other sources that contribute to background $\mathrm{O}_{3}$.

Stratosphere-to-troposphere transport (STT) [Stohl et al., 2003a] has previously been implicated in springtime exceedances of the 1997 NAAQS of 85 ppbv in Colorado [Langford et al., 2009] and the 2008 NAAQS of 75 ppbv in Wyoming [State of Wyoming, 2013], Nevada [Langford et al., 2015b], California [Langford et al., 2012], Arizona, and New Mexico [Lin et al., 2012a]. More frequent exceedances are expected under the 70 ppbv NAAQS, making application of the Exceptional Events Rule even more difficult. The disproportionate contribution of STT to surface ozone in the southwestern U.S. seen in Figure 1 can be explained in part by a higher incidence of deep stratospheric intrusions above the west coast of North America during springtime [James et al., 2003; Skerlak et al., 2014; Sprenger and Wernli, 2003; Stohl et al., 2003a; Stohl et al., 2003b; Wernli and Bourqui, 2002]. These intrusions, which typically begin as tropopause folds extruded beneath the jet stream circulating around upper level cyclones approaching the Pacific Northwest, slope isentropically downward toward the equator and often approach to within $4 \mathrm{~km}$ of the surface by the time they reach Southern California, Nevada, and Arizona [Browell et al., 1987; Danielsen et al., 1987; Langford et al., 2012]. Tropopause folds are most common in winter and early spring when midlatitude cyclonic activity is at a maximum [Holton et al., 1995], but the potential influence on surface air quality peaks in late spring and early summer when ozone is more abundant in the lower stratosphere [Prather et al., 2011], photochemical production is increasing in the troposphere, and convective mixing in the boundary layer is more vigorous [Stull, 1988].

Another factor contributing to the spatial distributions in Figure 1 is the higher average elevation of the western U.S., which increases the potential for isentropically descending stratospheric air and transported pollution to directly intersect the surface, sink to the ground behind cold fronts [Kunz and Speth, 1997], become entrained in the mixed layer [Johnson and Viezee, 1981], or impinge on the high peaks of the Sierra Nevada or Rocky Mountains [Langford et al., 2009]. Descending lower stratospheric air has long been associated with transient increases in ozone at alpine sites [Altmanspacher and Hartmannsgruber, 1973; Ambrose et al., 2011; Schuepbach et al., 1999; Stohl et al., 2000; Trickl et al., 2010; Trickl et al., 2014], leading to the widespread belief that STT is only important at sparsely populated high-elevation sites. However, STT has also been implicated in transient ozone increases near sea level [e.g., Akritidis et al., 2010; Dempsey, 2014; Lamb, 1977; Langford et al., 2015a; Lefohn et al., 2011; Lefohn et al., 2012], and measurements made during the 2010 California Nexus (CalNex) study [Ryerson et al., 2013] documented transport of lower stratospheric air to the surface in the Los Angeles Basin and nearby Mojave desert [Langford et al., 2012].

In this paper, we examine the contributions of STT and transported pollution to exceedances of the $75 \mathrm{ppbv}$ NAAQS at lower elevation (i.e., less than $900 \mathrm{~m}$ above mean sea level (asl)) sites in Clark County, NV, during the first week of the Las Vegas Ozone Study (LVOS) [Langford et al., 2015b]. Our analysis suggests that the exceptionally deep (3-5 km asl) convective boundary layers that form above the Mojave desert in late spring [Fine et al., 2015a; Fine et al., 2015b; Seidel et al., 2012] were able to entrain air from stratospheric intrusions and associated Asian pollution that had passed intact over the shallower boundary layers of the San Joaquin Valley and the Sierra Nevada Mountains. We hypothesize that this process, which can impact major population centers like Las Vegas and Phoenix in addition to remote areas like the Death Valley, Grand Canyon, and Great Basin National Parks [Gustin et al., 2015], is a major contributor to the springtime ozone maximum in the southwestern U.S. and will complicate implementation of the lower 70 ppbv NAAQS in this region.

\section{Las Vegas Ozone Study (LVOS)}

The Las Vegas Ozone Study (LVOS) was conducted at Angel Peak, NV (cf. Figures 1 and 2), between 19 May and 26 June 2013 by the NOAA Earth System Research Laboratory Chemical Sciences Division (ESRL CSD). LVOS was designed specifically to investigate the influence of STT and long-range transport from Asia on surface ozone concentrations in Clark County, NV, which includes the greater Las Vegas metropolitan area. The findings have been summarized in an overview paper [Langford et al., 2015b]. Here we focus on measurements made during the first week (19-26 May) of the campaign when the appearance of several 

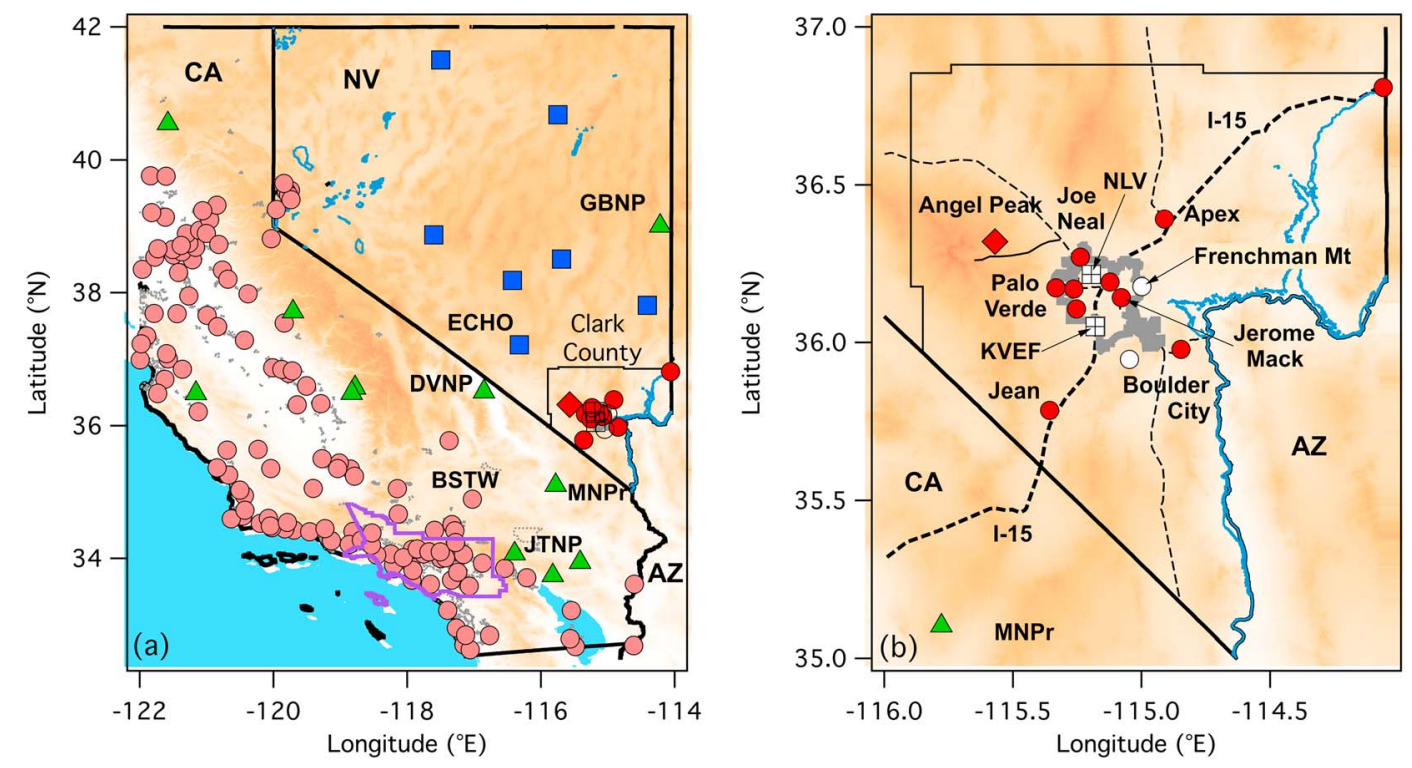

Figure 2. (a) Relief map of Nevada and eastern California showing the locations of ozone monitors operated by state and local agencies (filled circles), the National Parks Service (green triangles), NVROI (blue squares), and NOAA (Angel Peak; diamond). The monitors at the Great Basin (GBNP), Death Valley (DVNP), and Joshua Tree (JTNP) National Parks and the Mojave National Preserve (MNPr) are marked, along with Barstow, CA (BSTW), and the NVROI monitor at Echo Peak. The South Coast Air Basin is outlined in violet. Monitors in Clark County are shown in red. (b) Enlarged view of Clark County showing the location of Angel Peak relative to the Clark County regulatory (filled circles) and nonregulatory (open circle) ozone monitors. The heavy and light solid black lines show the state and Clark County borders, respectively, and the dashed lines represent the major roads. The Las Vegas metropolitan area is outlined in gray. KVEF and NLV are the McCarran International and North Las Vegas Airports, respectively.

stratospheric intrusions above Angel Peak coincided with several days of high surface ozone in and around Clark County and exceedances of the 75 ppbv NAAQS on 21 and 25 May.

Angel Peak $\left(36.32^{\circ} \mathrm{N}, 115.57^{\circ} \mathrm{W}\right)$ is located $45 \mathrm{~km}$ NW of Las Vegas in the Spring Mountains massif. The summit ( $2682 \mathrm{~m}$ asl) is occupied by a decommissioned U.S. Air Force radar base that is now maintained by the Federal Aviation Administration and Clark County as a radar/communications facility. This prominent peak overlooks the Las Vegas Valley (LVV), which has an average elevation of $620 \mathrm{~m}$ asl and is home to the Las VegasParadise-Henderson Metropolitan Statistical Area with a population of more than 2,000,000. The site is isolated with no local $\mathrm{NO}_{\mathrm{x}}$ or $\mathrm{CO}$ emissions other than those associated with the periodic testing of backup generators. Clark County also operates the Spring Mountain Youth Camp (SMYC), a residential correctional facility located about $300 \mathrm{~m}$ below and $1 \mathrm{~km}$ west of the summit at the former air base cantonment. Access to the SMYC and the summit is restricted, but spikes in $\mathrm{CO}$ and $\mathrm{O}_{3}$ destruction caused by SMYC staff traffic were occasionally detected at the summit during the early morning hours when the winds were calm.

LVOS was based around Tunable Optical Profiler for Aerosols and oZone (TOPAZ), the CSD mobile scanning ozone lidar system [Alvarez et al., 2011; Langford et al., 2011], which was deployed to the summit of Angel Peak for the campaign. This truck-mounted lidar system couples a zenith-pointing telescope and multiwavelength solid-state ultraviolet laser with a large scanning mirror to sequentially measure ozone and backscatter along slant paths that are projected on the vertical axis to create profiles ranging from $\sim 20 \mathrm{~m}$ to $3 \mathrm{~km}$ above ground level (agl). During LVOS, $5 \mathrm{~min}$ averaged vertical profiles were constructed from projections of 1 min slant profiles acquired sequentially at elevation angles of $90^{\circ}, 20^{\circ}$, and $6^{\circ}$, and $2^{\circ}$ above the horizon. The low-elevation measurements allow nearly direct comparisons to the collocated in situ measurements and show that the influence of horizontal variability is minimized by the $5 \mathrm{~min}$ averaging time. The system is automated, but not autonomous, and does not operate continuously. Ozone mixing ratio profiles are derived from the measured $\mathrm{O}_{3}$ number densities corrected for differential Rayleigh and aerosol backscatter and extinction using an atmospheric density profile based on the measured surface temperature and the standard atmospheric lapse rate [Alvarez et al., 2011]. TOPAZ is part of the NASA-supported Tropospheric Ozone Lidar Network or TOLNet (http://www-air.larc.nasa.gov/missions/TOLNet/). 
The lidar observations at Angel Peak were augmented by continuous 1 min surface measurements of $\mathrm{O}_{3}$, carbon monoxide (CO), wind speed, wind direction, pressure, and relative humidity at the summit. Since most atmospheric $\mathrm{CO}$ originates from sources at the Earth's surface, either directly from natural or anthropogenic combustion processes or indirectly through oxidation of $\mathrm{CH}_{4}$ and other volatile organic compounds (VOCs) emitted at the surface [Warneck, 1988], it is often used as a tracer for transported pollution and wildfire influences [Ambrose et al., 2011]. Ozone and CO are usually correlated in air with strong anthropogenic influences but anticorrelated in air originating from the stratosphere. The $\mathrm{O}_{3}$ and $\mathrm{CO}$ concentrations at Angel Peak were measured in air sampled $12 \mathrm{~m}$ above the surface, and the meteorological parameters were measured at $3 \mathrm{~m}$. Ozone was measured using a commercial UV-absorbance monitor with a detection limit of 1 ppbv for a $1 \mathrm{~min}$ integration time and an uncertainty of $2 \%$ [Williams et al., 2006]. This instrument was calibrated against a reference standard in the laboratory prior to deployment. Carbon monoxide was measured using a modified commercial vacuum ultraviolet fluorescence monitor [Holloway et al., 2000] with a detection limit below 1 ppbv for a $1 \mathrm{~min}$ integration time and an accuracy of $4 \%$. This instrument was zeroed and calibrated hourly using a gaseous reference standard.

The Angel Peak measurements are augmented by hourly surface $\mathrm{O}_{3}$ observations recorded by federal, state, tribal, county, and local regulatory monitors and obtained from the U.S. EPA Air Quality System (https:// www3.epa.gov/airquality/airdata/). Hourly data were also obtained from the Nevada Rural Ozone Initiative (NVROI) [Gustin et al., 2015] established by the University of Nevada at Reno, which operated eight research monitoring stations at remote locations across Nevada during LVOS. Five-minute data from $\mathrm{O}_{3}$ monitors in the greater Las Vegas area were obtained from the Clark County Department of Air Quality (CC-DAQ), and the U.S. National Park Service (NPS) provided 1 min data from monitors in the Death Valley, Great Basin, Zion, and Grand Canyon National Parks. All of these monitors use UV photometers traceable to federal standard reference photometers. The locations and affiliations of these monitors are shown in Figure 2. Surface meteorological data for Clark County and surrounding areas were obtained from the CC-DAQ and from the MesoWest network [Horel et al., 2002]. Upper air information was obtained from the twice-daily soundings at the McCarran International Airport (VEF). An integrated upper air monitoring station consisting of a radar wind profiler, solar, and a profiling radiometer operated by the CC-DAQ at the North Las Vegas Airport was not operational during the field campaign.

\section{Model Descriptions and Analyses}

\subsection{Model Descriptions}

The NOAA National Environmental Satellite, Data, and Information Service Real-time Air Quality Modeling System (RAQMS) [Pierce et al., 2003; Pierce et al., 2007] and the FLEXible PARTicle (FLEXPART) Lagrangian dispersion model [Brioude et al., 2007; Stohl et al., 2005] were used to forecast STT and long-range transport events during the LVOS measurement campaign. The NOAA GFDL AM3 chemistry-climate model [Fiore et al., 2014; Lin et al., 2012a; Lin et al., 2012b] was then used along with RAQMS and FLEXPART to help estimate the contributions of STT and long-range transport to surface ozone in Clark County.

RAQMS is a unified (stratosphere-troposphere) online global chemical and aerosol assimilation/forecasting system that has been used to support several airborne field campaigns. Forecasts were initialized daily at 12 UT with real-time assimilation of Ozone Monitoring Instrument cloud-cleared total column ozone and Microwave Limb Sounder ozone profiles from the NASA Aura satellite and Moderate Resolution Imaging Spectroradiometer aerosol optical depth from the NASA Terra and Aqua satellites. The total $\mathrm{O}_{3}$ and $\mathrm{CO}$ (see supporting information) distributions from East Asia to North America ( 10 to $72^{\circ} \mathrm{N}, 110$ to $-50^{\circ} \mathrm{E}$ ) were predicted at $6 \mathrm{~h}$ intervals for the next 4 days. RAQMS has been run routinely since 2010 with $2^{\circ} \times 2^{\circ}$ resolution analyses and forecasts prior to 2012 and $1^{\circ} \times 1^{\circ}$ resolution after 2012 . RAQMS analyses since 2010 are archived online (http://raqms-ops.ssec.wisc.edu).

FLEXPART is a passive tracer model with no chemistry or surface losses that calculates the evolving distribution of a multitude of "particles" transported forward in time from a specified source region or backward in time from a specific receptor location. The particles are transported both by the resolved winds and by parameterized subgrid motions including turbulence and convection. For the present study, FLEXPART was driven by the National Centers for Environmental Prediction (NCEP) Global Forecast System (GFS) model (analyses at 00, 06, 12, and 18 UT; $3 \mathrm{~h}$ forecasts at 03, 09, 15, and $21 \mathrm{UT}$ ) and run at a spatial resolution 
of $0.5^{\circ} \times 0.5^{\circ}$ with 26 vertical levels. FLEXPART parameterizes turbulence in the boundary layer using the Hanna turbulence scheme [Hanna, 1982] and uses the convection parameterization scheme of Emanuel and Zivkovic-Rothman [1999], which is implemented at each 15 min model time step and is intended to describe all types of convection. This scheme includes entrainment and mixing, cloud microphysical processes, and large-scale control of ensemble convective activity, including the interaction between convective downdrafts and surface fluxes.

The FLEXPART stratospheric $\mathrm{O}_{3}$ tracer was carried by particles released into the stratosphere ( $>2$ potential vorticity units or PVU) and the $\mathrm{O}_{3}$ mixing ratios calculated using a linear relationship between $\mathrm{O}_{3}$ and potential vorticity ( $60 \mathrm{ppbv} / \mathrm{PVU}$ at the particle origin in the stratosphere). The particle distribution was then recalculated for up to 20 days. FLEXPART tracers for Asian and North American pollution (see supporting information) are based on the amount of $\mathrm{CO}$ released into the boundary layer from anthropogenic sources in East Asia and North America, respectively, using the EDGAR 3.2 fast track inventory [Olivier et al., 2005]. These tracers were also followed for 20 days. Since FLEXPART is a passive model with no chemistry or surface losses, it cannot directly quantify the amount of $\mathrm{O}_{3}$ in Asian pollution plumes, but previous studies suggest that the $\mathrm{O}_{3}$ concentrations in these plumes are typically about a factor of 3 lower than the $\mathrm{CO}$ concentrations [Heald et al., 2003].

The NOAA/GFDL AM3 chemistry-climate model includes interactive stratospheric and tropospheric chemistry, nudged to NCEP GFS winds [Lin et al., 2012a; Lin et al., 2012b]. The AM3 simulation of STT $\mathrm{O}_{3}$ is entirely driven by winds, with no dependency on the tropopause definition. We implement a stratospheric ozone tracer, defined relative to the dynamically varying e90 tropopause [Prather et al., 2011], to quantify ozone originating from the stratosphere and account for loss processes in the troposphere. This component can be isolated from the total tropospheric concentrations, which include photochemically produced ozone from both anthropogenic and natural sources. These analyses use a new version of GFDL AM3 with a C90 cubed-sphere grid resolution of $\sim 100 \times 100 \mathrm{~km}^{2}$ and daily resolving fire and anthropogenic emissions.

AM3 uses the planetary boundary layer (PBL) scheme of Lock et al. [2000], which includes representation of nonlocal mixing in unstable layers and an explicit entrainment parameterization. AM3 accurately reproduces the observed spatial, seasonal, and diurnal variabilities of PBL heights over the U.S. but tends to overestimate shallow, stable nighttime and winter PBL heights [Seidel et al., 2012]. Comparison of the diurnal and day-to-day variabilities of $A M 3$ surface $\mathrm{O}_{3}$ between the free-running climate model and the nudged version suggests that nudging does not perturb transport from the Fourier transform to the PBL.

\subsection{Model Analyses}

The polar jet stream was very active during the second half of May 2013 (https://www.ncdc.noaa.gov/sotc/ synoptic/201305) with a series of closely spaced midlatitude cyclones moving into the Pacific Northwest from the North Pacific Ocean. Two of these deep low-pressure systems are shown in Figure 3, which displays the 12 UT (05 Pacific Daylight Time (PDT)) $300 \mathrm{hPa}$ geopotential heights and winds from the $\left(0.3^{\circ} \times 0.3^{\circ}\right)$ National Centers for Environmental Prediction/North American Regional Reanalysis (NCEP/NARR) for 20 and 24 May 2013. Figure 3a shows a deep trough above Colorado, Wyoming, and Nebraska on 20 May, with a moderate $\left(>45 \mathrm{~m} \mathrm{~s}^{-1}\right)$ localized wind maximum or jet streak embedded in the circulation around the southerly flank above New Mexico and North Texas (Figure 3c). Slightly weaker winds can be seen over Nevada. This system was closely followed by the next cyclone, which is centered over the Pacific Northwest at 12 UT (05 PDT) on 24 May (Figure 3b). This second low was much deeper than the first and closed (but not cutoff) in the $300 \mathrm{hPa}$ circulation. Figure 3d shows a weaker jet streak on the southeastern flank of this cyclone above Montana, Idaho, and Wyoming. These two systems created severe springtime weather across much of the U.S. including two major tornado outbreaks in the Midwest and Southern Plains [Gravelle et al., 2016] and record late season snowfall on the East Coast.

The 12 UT (05 PDT) 20 and 24 May GOES-West water vapor images in Figures 4a and 4b exhibit bright greento-yellow colors indicative of cool, moist, and cloudy air in the centers of the troughs, with deep blue and purple bands characteristic of warm, dry air wrapping around the southerly flanks. These low radiance "dry slots" lie between about 400 and $200 \mathrm{hPa}$ (roughly 7 to $11 \mathrm{~km}$ asl) and are usually caused by lower stratospheric air descending into the upper troposphere. This interpretation is supported by the 12 UT (05 PDT) RAQMS $\mathrm{O}_{3}$ analyses displayed in Figure 5, which show similar bands of high $\mathrm{O}_{3}$ on the $320 \mathrm{~K}$ (top), $310 \mathrm{~K}$ (middle), and 
(a) 12UT May 20, $2013 \quad 300 \mathrm{hPa}$ hgts

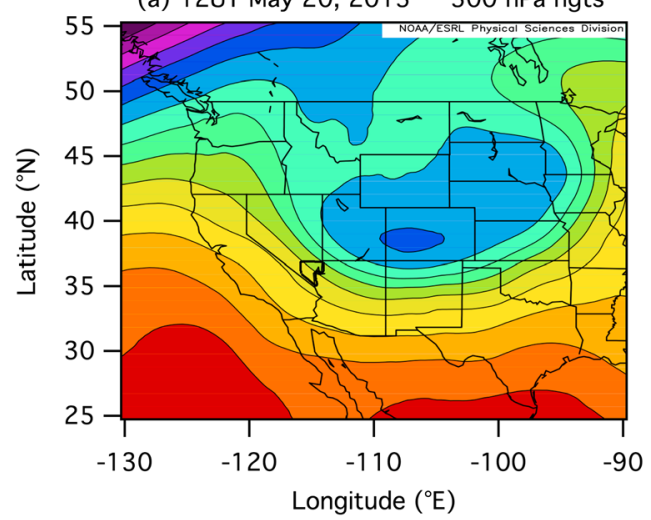

(c) 12UT May 20, $2013 \quad 300 \mathrm{hPa}$ winds

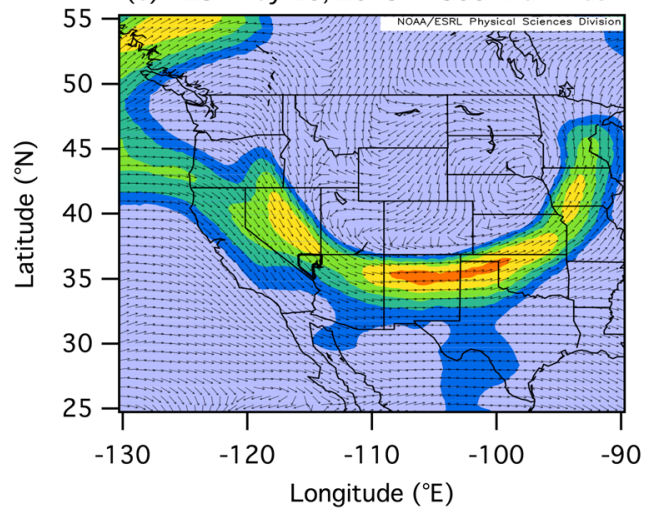

(b) 12UT May 24, $2013 \quad 300 \mathrm{hPa}$ hgts

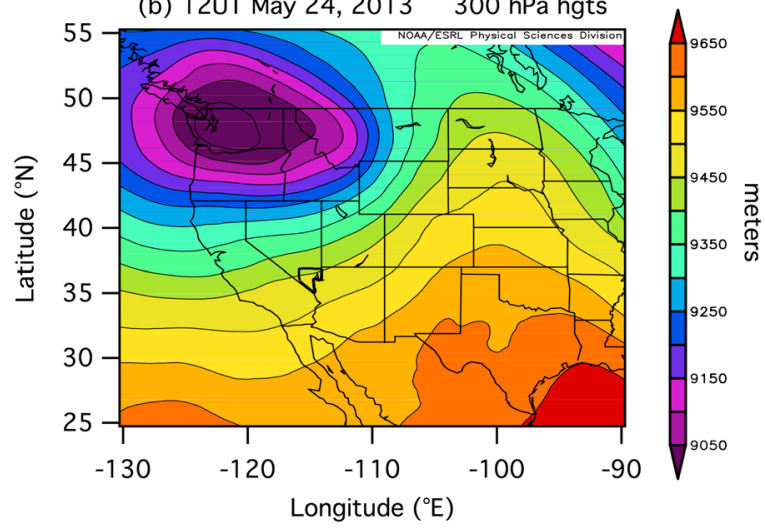

(d) 12UT May 24, $2013 \quad 300 \mathrm{hPa}$ winds

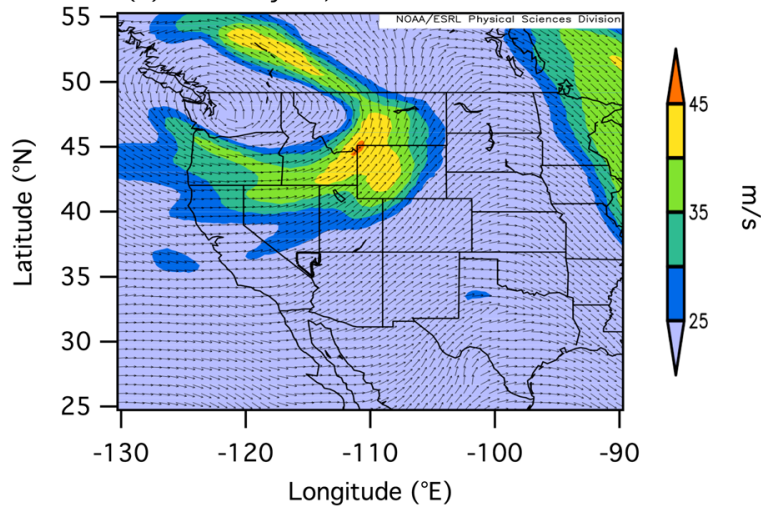

Figure 3. The (top) $300 \mathrm{hPa}$ geopotential heights and (bottom) winds for 12 UT (05 PDT) on (left) 20 May and (right) 24 May from the NCEP North American Regional Reanalysis (NARR). These plots were created using the NOAA ESRL Physical Sciences Division (PSD) online resources (http://www.esrl.noaa.gov/psd/data/narr/).

$300 \mathrm{~K}$ (bottom) isentropic surfaces. The white contours in Figure 5 represent the corresponding altitudes, which are roughly 6-7, 4-5, and 2-3 km asl over southern Nevada. The RAQMS CO distributions are shown in the supporting information.

The $320 \mathrm{~K} \mathrm{RAQMSO}_{3}$ analysis for 20 May (Figure 5a) shows a band of high ozone consistent with a descending lower stratospheric air wrapping cyclonically around the low-pressure center beneath the jet (cf. Figure 3c). This band is displaced equatorward in the $310 \mathrm{~K}$ analyses (Figure $5 \mathrm{c}$ ) as would be expected for an isentropically sloping tropopause fold similar to the classical model of Danielsen [1968]. Figure $5 \mathrm{c}$ shows high ( $>100 \mathrm{ppbv})$ $\mathrm{O}_{3}$ above most of Nevada at $310 \mathrm{~K}(4-5 \mathrm{~km}$ asl), with lower concentrations (65-70 ppbv) at $300 \mathrm{~K}(2-3 \mathrm{~km}$ asl; Figure 5e). The 24 May analyses on the right side of Figure 5 appear qualitatively different, with the highest ozone in the center of the closed low.

Figure $5 \mathrm{~d}$ shows a filament with $80-90$ ppbv of ozone projecting from the closed low beneath the jet streak (cf. Figure 3d) and trailing southwestward across Nevada from Utah to California between 4 and $5 \mathrm{~km}$. The absence of a significant horizontal displacement between this filament on the $310 \mathrm{~K}$ (Figure $5 \mathrm{~d}$ ) and $300 \mathrm{~K}$ (Figure 5f) surfaces suggests that it was aligned vertically beneath the jet axis. The filament coincides with the dry slot stretching across California to southern Nevada in Figure 4b. Note that the more southerly dry slot above Baja California and Arizona in Figure $4 \mathrm{~b}$ corresponds to lower $\mathrm{O}_{3}$ and $\mathrm{CO}$ (Figure $\mathrm{S} 1$ in the supporting information) on the RAQMS surfaces. This reflects the fact that warm, subtropical air lofted into the middle and upper troposphere at low latitudes can also decrease the net radiance in water vapor imagery.

Figure 6 displays the 12 UT (05 PDT) 20 and 24 May FLEXPART stratospheric $\mathrm{O}_{3}$ tracer (ST) distributions in the free troposphere between 3 and $6 \mathrm{~km}$ asl (top plots) and in the boundary layer below $1.5 \mathrm{~km}$ (bottom plots). The corresponding Asian and North American CO tracer distributions are shown in Figures S2 and S3. The FLEXPART ST $\mathrm{O}_{3}$ for 12 UT (05 PDT) on 20 May (Figure 6a) appears qualitatively similar to the 310 K RAQMS 

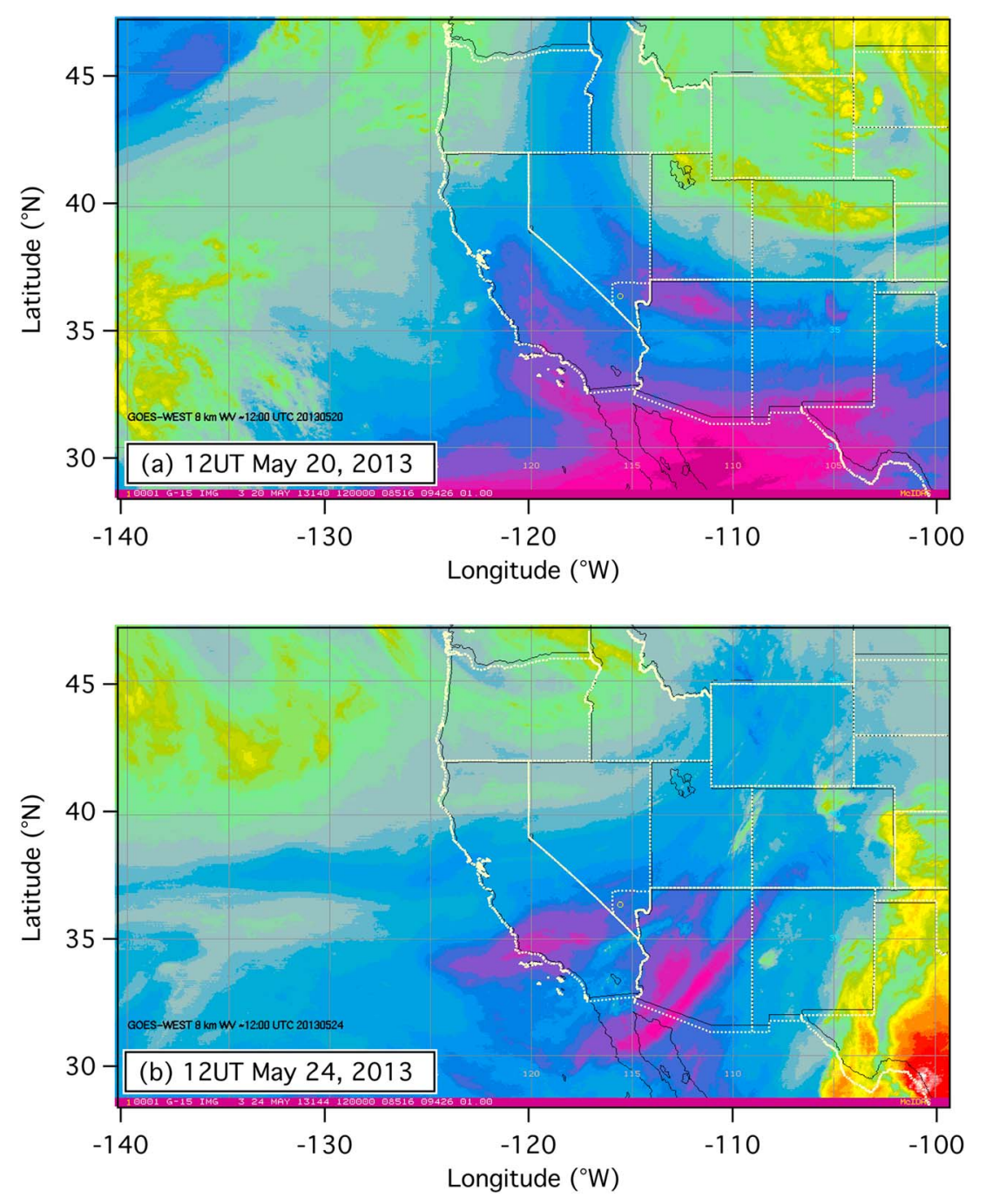

Figure 4. GOES-West water vapor images from 12 UT (05 PDT) on (a) 20 May and (b) 24 May 2013. The deep blue/purple bands show very dry air in the upper free troposphere $(\sim 7$ to $10 \mathrm{~km})$. Images courtesy of Dr. Owen Cooper.

distributions in Figure $5 c$, supporting a stratospheric origin for the high $\mathrm{O}_{3}$. The tracer shows concentrations in excess of 50 ppbv above Nevada, which compares well with the concentration gradient from Utah to Nevada across the filament seen in the $310 \mathrm{~K}$ RAQMS analysis (Figure $5 \mathrm{c}$ ). The ST tracer concentrations in the boundary layer at 12 UT (05 PDT) on 20 May (Figure 6c) were less than 10 ppbv over Clark County but increased to more than $30 \mathrm{ppbv}$ over the next $36 \mathrm{~h}$ (not shown). The ST tracer distributions on the morning of 24 May showed 10-15 ppbv in the free troposphere (Figure 6b) above Nevada and 15-20 ppbv in the boundary layer (Figure $6 \mathrm{~d}$ ). These results are also consistent with the 310 and $300 \mathrm{~K}$ RAQMS analyses (Figures $5 \mathrm{~d}$ and $5 \mathrm{f}$ ), which show gradients of about 20 ppbv across the high-ozone filament.

The RAQMS and FLEXPART CO distributions (Figures S1-S3) for 20 and 24 May are also qualitatively different, with much more $\mathrm{CO}$ in the free troposphere above the Southwest during the first event. The $310 \mathrm{~K}$ (Figure S1C) and $300 \mathrm{~K}$ (Figure S1e) RAQMS CO distributions for 20 May show bands of elevated (125-145 ppbv) CO (yellow-green) on either side of the high-ozone band consistent with transport of polluted air across the Pacific by the first cyclonic system. This interpretation is supported by the FLEXPART Asian CO tracer distributions in Figure S2, which also show diffuse bands of CO wrapping around the cyclone in both the free troposphere and boundary layer. Figure S2c shows about 10 to 20 ppbv of Asian CO in the boundary layer above Nevada on 20 May, which roughly corresponds to 3 to $7 \mathrm{ppbv}$ of $\mathrm{O}_{3}$ in the pollution plume [Heald et al., 2003]. The FLEXPART Asian CO tracer distribution for 24 May shows a well-defined band of CO ahead of the high-ozone filament beneath the jet to the east of Clark County. 


\section{AGU. Journal of Geophysical Research: Atmospheres}
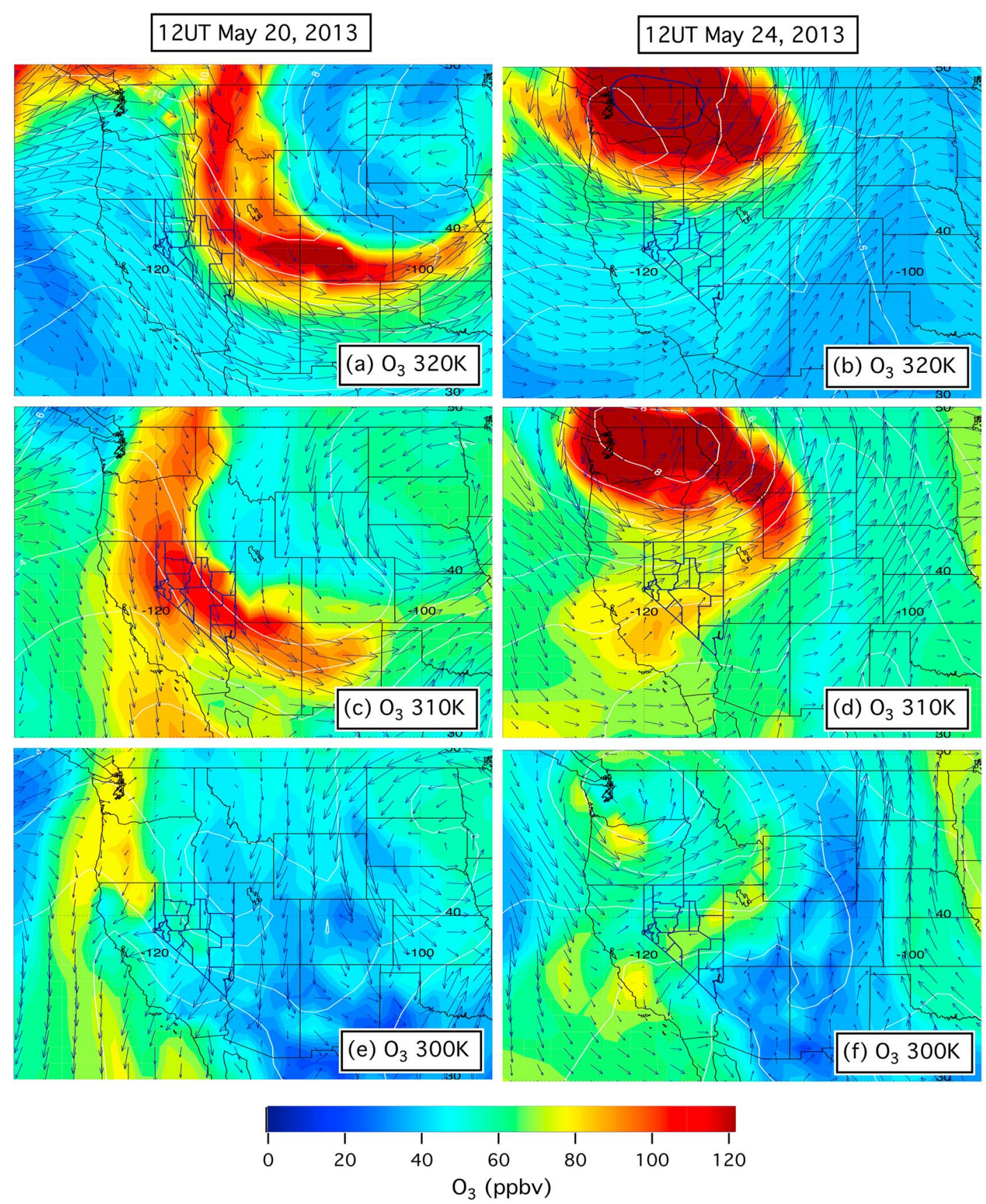

Figure 5. RAQMS total $\mathrm{O}_{3}$ distributions for 12 UT (05 PDT) on (left) 20 May and (right) 24 May 2013. The distributions on the (top) 320, (middle) 310, and (bottom) $300 \mathrm{~K}$ isentropic surfaces are shown, and the white contour lines show the approximate altitudes which roughly correspond to 6-7, 4-5, and 2-3 km asl, respectively, over southern Nevada.

The $300 \mathrm{~K}$ RAQMS CO analysis for 20 May (Figure S1e) also indicates that there was more CO from North American sources on 20 May, including a plume originating from agricultural fires in southern Mexico that passed over Texas and Oklahoma to wrap cyclonically around the surface low over the eastern Dakotas. Figure S1e also shows high $\mathrm{CO}$ within the boundary layer over most of California and southern Arizona with prominent hot spots over Los Angeles and the South Coast Air Basin (SoCAB; cf. Figure 2a) and Tijuana, Mexico. These hot spots do not appear on the $310 \mathrm{~K}$ surface, which suggests that most of this pollution remained in the boundary layer. FLEXPART (Figure S3) shows the Los Angeles plume flowing east across southern Arizona and New Mexico on the morning of 20 May but passing directly over Clark County 2 days 

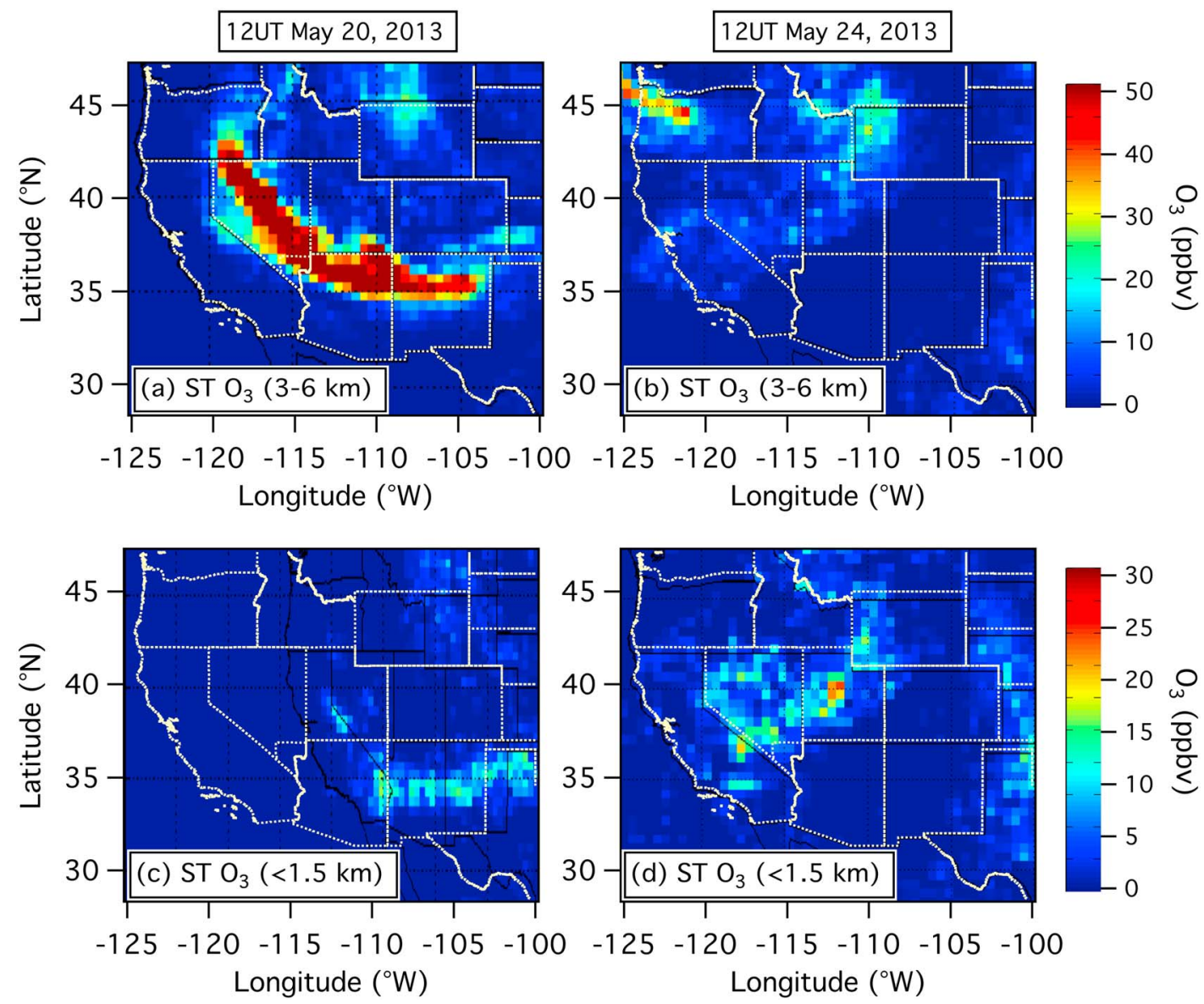

Figure 6. FLEXPART stratospheric $\mathrm{O}_{3}$ tracer (ST) distributions for 12 UT (05 PDT) on (left) 20 May and (right) 24 May 2013. (top) The distributions in the free troposphere (3-6 km asl) and (bottom) the distributions in the boundary layer $(<1.5 \mathrm{~km}$ asl).

later on 22 May (not shown) and on 24 May (Figure S3d) when the plume is entrained by the southwesterly midtropospheric jet.

The contributions of the 20 and 24 May stratospheric intrusions to surface ozone in the southwestern U.S. were also estimated using the AM3 model. Figures 7 and 8 show the $A M 3 M D A 8 \mathrm{O}_{3}$ distributions for the two 3 day periods of 20-22 and 24-26 May, respectively. The plots in these figures show (from left to right) the total calculated surface $\mathrm{O}_{3}$, the contribution from $\mathrm{ST}$, and the difference between the two, which includes contributions from background $\mathrm{O}_{3}$, Asian pollution, and local and regional production. Figure 7 shows that the model surface concentrations exceeded 70 ppbv over much of the Southwest on 20-22 May, with STT contributions in excess of 25 ppbv over a large area including 40 ppbv over Clark County on 20 May. The biggest surface impacts lie equatorward of the free tropospheric ozone bands in Figure 5 as would be expected for an isentropically descending tropopause fold. The STT contributions are largest on 20 and 22 May, with modeled contributions in excess of 50 ppbv above northern Nevada on 22 May. The difference plots in Figure 7 suggest that there may also have been significant low-level transport of $\mathrm{O}_{3}$ from the SoCAB across southern Nevada on 22 May in agreement with the FLEXPART analyses and previous studies [VanCuren, 2015]. Figure 8 shows that the model surface concentrations exceeded 60 ppbv over a large area again on 24-26 May, with calculated contributions of 25 to $40 \mathrm{ppbv}$ of $\mathrm{STT} \mathrm{O}_{3}$ over southern Nevada on 24 and 25 May. The difference plots suggest that there was also significant transport of ozone from the SoCAB into the interior Southwest on those days in agreement with the FLEXPART CO tracer.

Figure 9a compares the AM3-calculated MDA8 ozone concentrations at Angel Peak with the measurements from the NOAA research monitor, which became operational on 20 May. The dashed and dotted horizontal lines represent the 75 and 70 ppbv NAAQS, respectively. The AM3 model concentrations (heavy red line) were 


\section{AGU Journal of Geophysical Research: Atmospheres}

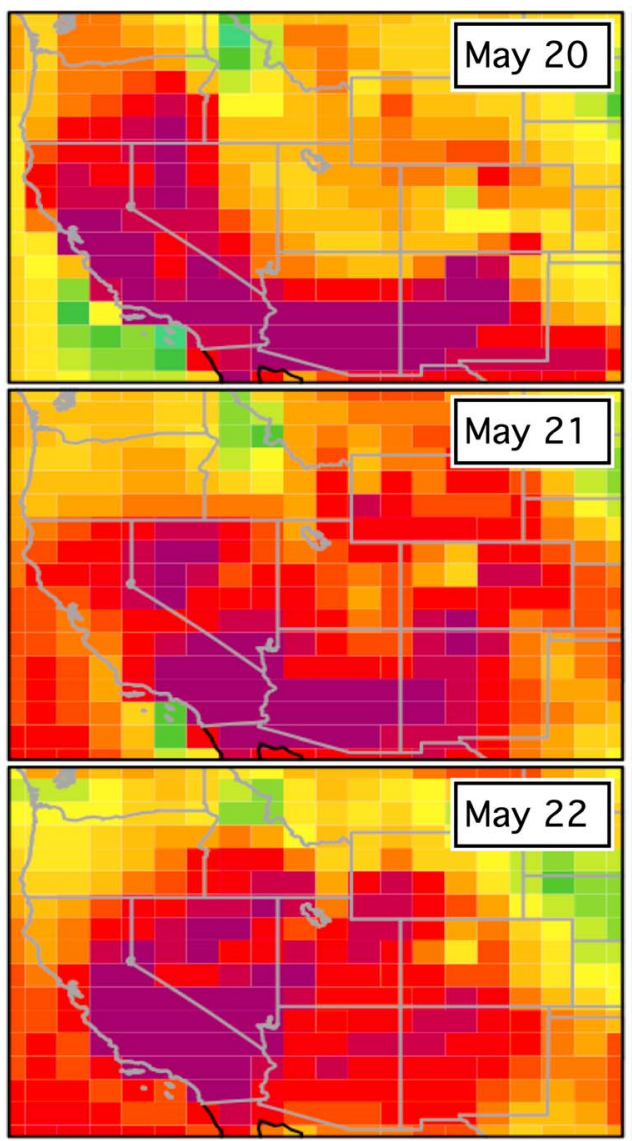

$\begin{array}{lllllllllll}20 & 25 & 30 & 35 & 40 & 45 & 50 & 55 & 60 & 65 & 70\end{array}$ AM3 Model Total (ppbv)
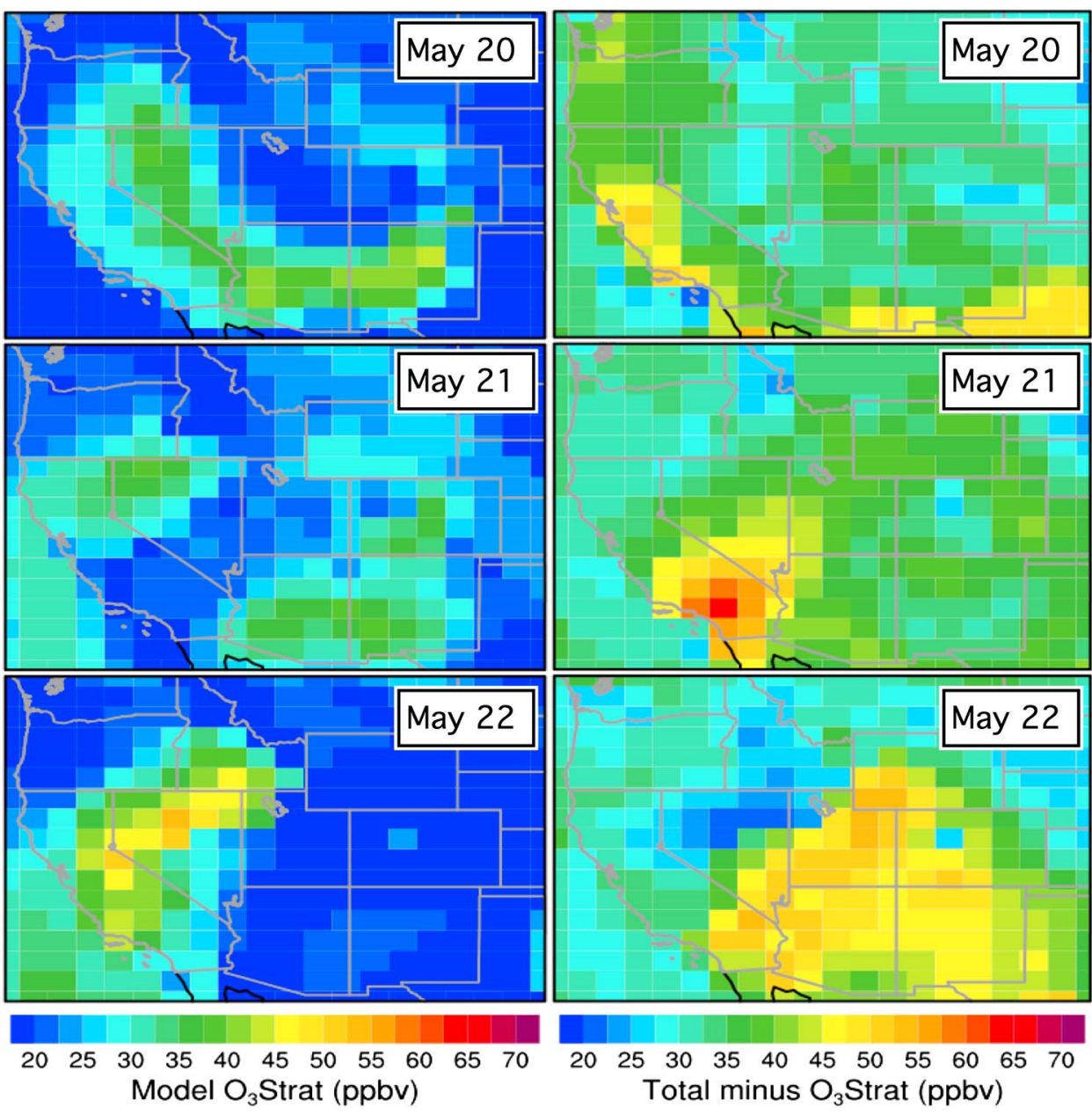

Figure 7. (top to bottom) AM3 surface ozone distributions for 20-22 May. (left to right) The plots display the total MDA8 surface ozone, the stratospheric contribution, and the difference.

typically about 5 ppbv higher (gray band) than the measurements between 20 and 25 May, consistent with previous findings [Lin et al., 2012a], but decreased more rapidly than the measurements after the passage of the second cyclone on 26 May. The model $\mathrm{ST} \mathrm{O}_{3}$ contributions ranged from $\sim 20$ to 45 ppbv between 18 and 25 May with the highest concentrations during the second event. The FLEXPART ST $\mathrm{O}_{3}$ tracer concentrations ranged from about 10 to $30 \mathrm{ppbv}$, with the highest contributions during the first event.

Figure $9 \mathrm{~b}$ is similar but shows the results for Joe Neal, one of the regulatory monitors maintained by Clark County in the Las Vegas Valley (cf. Figure 2). The mean RAQMS MDA8 ozone concentrations routinely calculated for this monitor are also shown. As before, AM3 tended to overestimate the measured concentrations by about 5 ppbv, while RAQMS tended to underestimate them by a slightly larger amount. The AM3 and FLEXPART stratospheric contributions were well correlated but differed by about 15 ppbv, with maximum contributions of about 20 and 35 ppbv from FLEXPART and AM3, respectively, during the first event, and 25 and 45 ppbv, respectively, during the second. Despite these differences, both models show the stratospheric contributions to surface ozone to be substantial on both of the exceedance days.

\section{Measurement Results}

\subsection{Angel Peak}

The ozone filaments in the RAQMS and FLEXPART free tropospheric distributions closely correspond with layers of high ozone detected by the TOPAZ lidar above Angel Peak and shown in the time-height curtain plot of Figure 10a. Ozone layers with mixing ratios in excess of $90 \mathrm{ppbv}$ were observed within $2.5 \mathrm{~km}$ of 

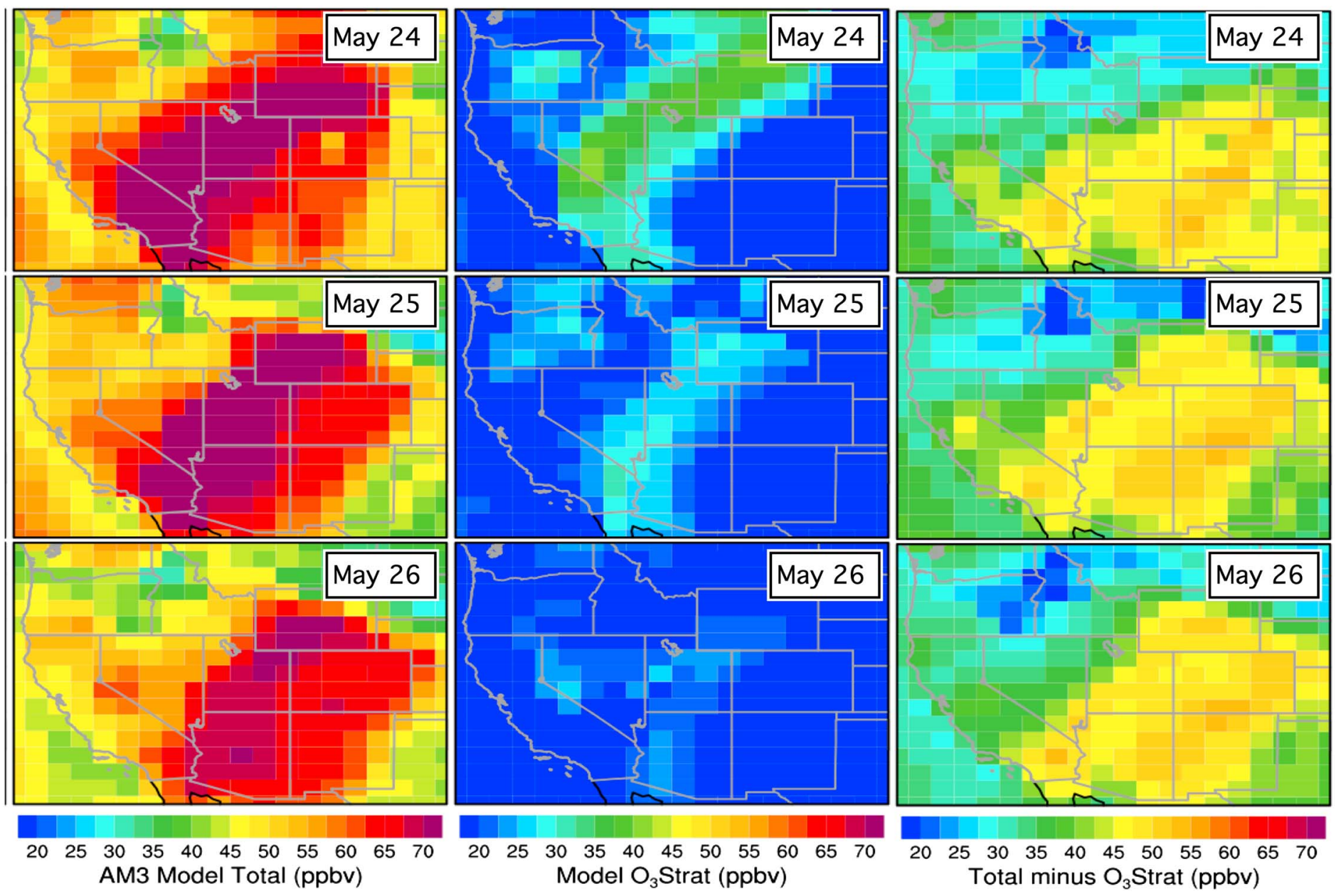

Figure 8. (top to bottom) AM3 surface ozone distributions for 24-26 May. (left to right) The plots display the total MDA8 surface ozone, the stratospheric contribution, and the difference.

the Angel Peak summit (i.e., between 2.7 and $5.2 \mathrm{~km}$ asl) on five of the days between 19 and 26 May, with mixing ratios greater than 120 ppbv measured on 19, 20, 24-25, and 26 May. Several of these layers reached the top of the planetary boundary layer (PBL; solid black line) derived from the $\left(0.3^{\circ} \times 0.3^{\circ}\right)$ National Centers for Environmental Prediction/North American Regional Reanalysis (NCEP/NARR) model [Mesinger, 2006]. These PBL heights, which were computed from a diagnostic formula using equilibrium turbulent kinetic energy [Janjić, 1996], and other NARR data were obtained from the NOAA ESRL Physical Sciences Division online plotting resources (http://www.esrl.noaa.gov/psd/data/narr/).

The NARR boundary layer heights usually extended well above the summit of Angel Peak during the study period and were mostly in good agreement with the mixed layer heights calculated from the afternoon (00 UT or 17 PDT) McCarran International Airport (VEF) soundings using the potential temperature gradient [Seidel et al., 2010] (filled white circles) between 19 and 26 May but were 500 to $1000 \mathrm{~m}$ lower than the VEF on 23 and 24 May (the 00 UT sounding on 20 May failed). Similar or slightly higher values were obtained using the parcel method. The height of the mixed layer varies spatially, and the values obtained from individual radiosonde profiles can differ significantly from the mean [Stull, 1988]; however, these potential errors should not affect the conclusions drawn from our analyses. The UV aerosol backscatter above Angel Peak was usually too weak to accurately determine the mixed layer height in the clean, dry conditions encountered during the first week of LVOS, but the heights obtained by this method (filled white triangles) on 19 and 24 May were also in good agreement with the VEF sounding depths. The backscatter gradient measurements also detected distinct aerosol layers (filled white squares) consistent with transported pollution about $1 \mathrm{~km}$ above the top of the NARR boundary layer on 20 and 26 May. 

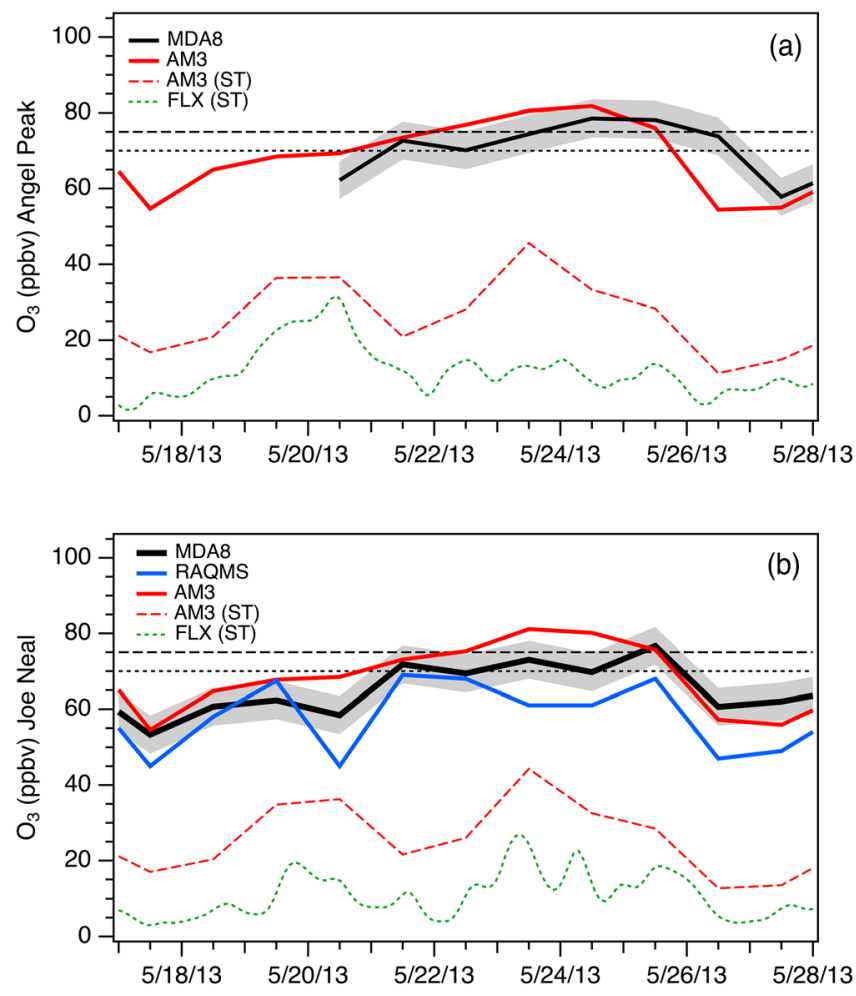

Figure 9. Time series of the measured and modeled (RAQMS and AM3) surface ozone at (a) Angel Peak and (b) Joe Neal. The heavy black traces show the measured concentrations with the gray band representing the measurements \pm 5 ppbv. The AM3 stratospheric contribution and FLEXPART ST tracer concentrations are also shown.
The lidar curtain plot in Figure 10a appears to show descent of $\mathrm{O}_{3}$ to the summit on several days, particularly 21 and 25 May, which were the two 75 ppbv NAAQS exceedance days in Clark County. This is consistent with the Angel Peak in situ $\mathrm{O}_{3}$ measurements, which are represented by the colored bar near the middle of Figure 10a and plotted as time series in Figures $10 \mathrm{~b}$ and 11 . Figure $10 \mathrm{~b}$ also plots the measurements from the Joe Neal monitor, and Figure 11 plots the surface $\mathrm{CO}$, specific humidity $\left(\mathrm{H}_{2} \mathrm{O}\right)$, wind speed and direction from Angel Peak, and the solar radiation from the nearby SMYC. The $\mathrm{O}_{3}$ and $\mathrm{NO}_{x}$ measurements from the Joe Neal monitor in the LVV are also included in Figures $11 \mathrm{a}$ and $11 \mathrm{~b}$, respectively. Note the convergence between the two $\mathrm{O}_{3}$ time series during most afternoons, including the exceedance days. The Angel Peak $\mathrm{O}_{3}, \mathrm{CO}, \mathrm{H}_{2} \mathrm{O}$, WS, and WD time series are colorized to reflect the comeasured specific humidity, which can be used as a convenient marker for distinguishing free tropospheric (drier) and bound-

ary layer (moister) influences. The $\mathrm{MDA}_{8} \mathrm{O}_{3}$ concentrations at the summit of Angel Peak remained above 70 ppbv for six consecutive days from 21 to 26 May, when both $\mathrm{CO}$ and $\mathrm{O}_{3}$ declined and the specific humidity increased as air influenced by the marine boundary layer arrived from the southwest. Figure 11 shows that $\mathrm{CO}$ generally decreased and $\mathrm{O}_{3}$ increased when very dry air was sampled at the summit of Angel Peak during the night. This suggests that some of the air reaching the surface during those nights had recently descended from the UT/LS [Langford et al., 2015b]. The arrows labeled A-D in Figure 11a point to specific peaks in the ozone time series created by filaments of middle and upper tropospheric air reaching the surface during the nights of 20-21, 21-22, and 24-25 May. The $\mathrm{O}_{3}$ and CO concentrations measured during these periods are displayed as scatterplots in Figure S4. In Figure S4a, the $\mathrm{O}_{3}$ and CO concentrations are completely uncorrelated, suggesting a UT/LS origin, but the small concentration ranges and relatively high specific humidities show that this air was substantially diluted by free tropospheric air by the time it reached the summit [Trickl et al., 2014]. The $\mathrm{O}_{3}$ and $\mathrm{CO}$ concentrations are positively correlated in Figure S4b, and the low specific humidities suggest that this peak was caused by a filament of Asian pollution transported to the surface from the middle or upper troposphere. Figures $\mathrm{S4c}$ and $\mathrm{S} 4 \mathrm{~d}$ show much drier air and negative correlations indicative of relatively undiluted air descending from the UT/LS during the night of 24-25 May.

The absence of similar negative $\mathrm{O}_{3}-\mathrm{CO}$ correlation during the day reflects the fact that while the summit of Angel Peak was always in the free troposphere at night, it was usually in the planetary boundary layer during the day and thus exposed to CO from sources in the LVV. Figure 11 also shows that the growth of the mixed layer beyond the summit of Angel Peak in the late morning was typically accompanied by a shift in wind direction and a spike in both $\mathrm{CO}$ and $\mathrm{H}_{2} \mathrm{O}$ as polluted air from the LVV reached the summit. The two small $\mathrm{CO}$ and $\mathrm{O}_{3}$ spikes observed during a period of strong southwesterly flow around local midnight on 22-23 May are consistent with transported pollution. 


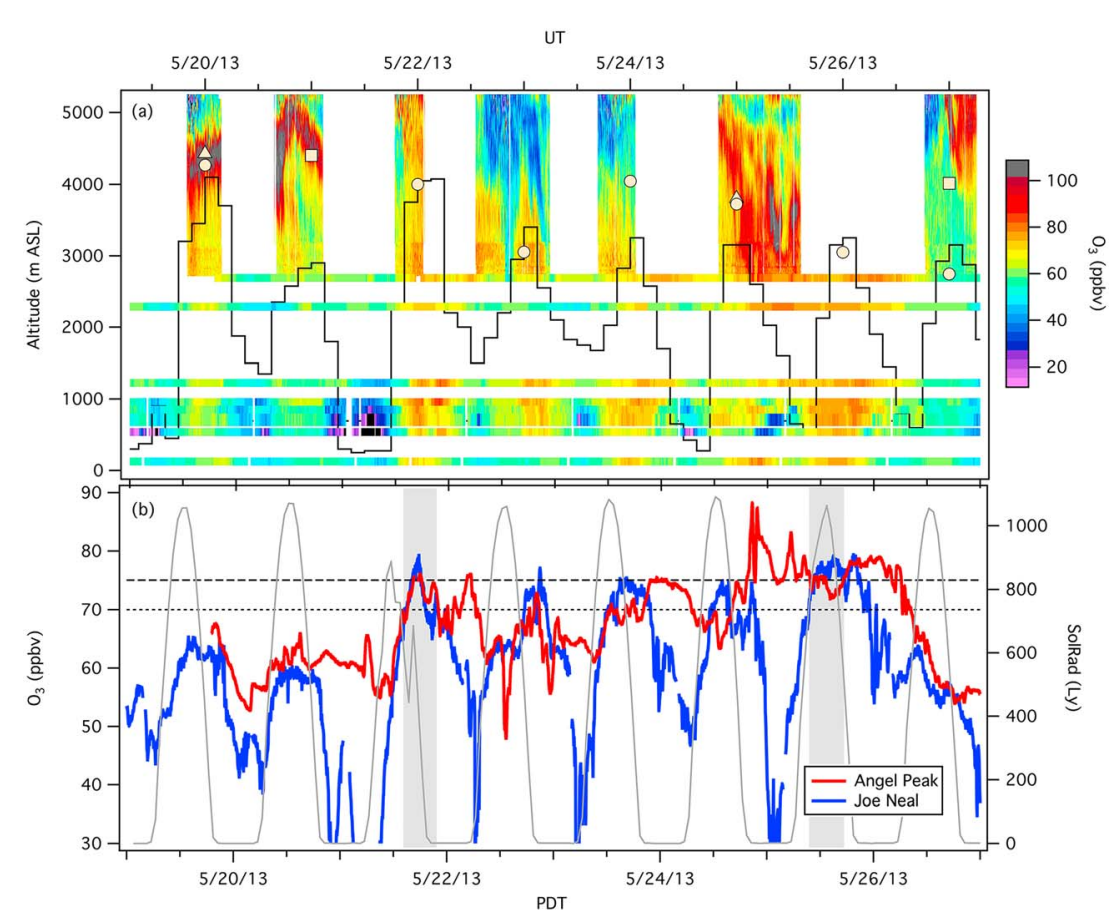

Figure 10. (a) Time-height curtain plots of the $\mathrm{O}_{3}$ mixing ratios above Angel Peak. The colored horizontal bars show the in situ concentrations at the summit (2682 $\mathrm{m}$ asl) and at the Echo Peak ( $2286 \mathrm{~m}$ asl), Frenchman Mountain (1216 $\mathrm{m}$ asl), Jean (924 m asl), Palo Verde (831 m asl), Joe Neal (709 m asl), and Jerome Mack (538 m asl) monitors. The lowest trace corresponds to the NPS monitor at Death Valley NP (125 m asl). The solid black line represents the NARR boundary layer height and the filled circles the mixed layer heights determined from the 00 UT (17 PDT) VEF soundings. The triangles and squares show the mixed layer heights or elevated aerosol layers, respectively, from the TOPAZ backscatter measurements. (b) Corresponding time series of the surface $\mathrm{O}_{3}$ measured at Angel Peak (red) and Joe Neal (blue). The smooth gray curves show the solar irradiance, and the dashed and dotted horizontal lines represent the 75 and 70 ppbv NAAQS. The gray bands highlight the two NAAQS exceedance events in Clark County.

\subsection{Las Vegas Valley}

High surface $\mathrm{O}_{3}$ was also measured by most of the Clark County monitors between 21 and 25 May, including those at Frenchman Mountain (1225 m asl), Jean (924 m asl), Palo Verde (851 m asl), Joe Neal (709 $\mathrm{m}$ asl), and Jerome Mack (538 m asl; cf. Figure 2b). These measurements are likewise depicted as altitude-sorted colored bars in Figure 10a. Jean is located outside the LVV and is usually upwind of Las Vegas but downwind of the SoCAB. Measurements from the NVROI monitor at Echo Peak $(2286 \mathrm{~m}$ asl) and the NPS monitor at Death Valley National Park (125 m asl) are also shown in Figure 10a. Death Valley and Echo Peak lie on the west side of the Spring Mountains about $115 \mathrm{~km}$ west-northwest and northwest, respectively, of Angel Peak.

The two highest-elevation Clark County monitoring sites are located about $60 \mathrm{~km}$ from Angel Peak: Frenchman Mountain, which lies across the LVV to the east-southeast, and Jean, which is situated in the high desert to the south. The three remaining monitors represented in Figure 10a lie within the LVV. The Palo Verde monitor is located on the western edge of the metropolitan area about $28 \mathrm{~km}$ from Angel Peak and $10 \mathrm{~km}$ east of the Red Rock Canyon National Conservation Area. Joe Neal lies about $32 \mathrm{~km}$ to the east of Angel Peak in the North Las Vegas metropolitan area, and Jerome Mack is located about $50 \mathrm{~km}$ to the eastsoutheast of Angel Peak near downtown Las Vegas, which is situated between the McCarran International Airport and Frenchman Mountain. The Frenchman Mountain monitor was installed temporarily for research purposes; the remaining monitors are operated year-round for regulatory purposes.

Concentrations at the LVV sites were very similar to those measured at Angel Peak during the afternoons but diverged during the night when shallow nocturnal boundary layers created by strong radiative cooling in the high desert decoupled the surface layer from the afternoon mixed layer. Similar patterns were observed at several of the NVROI sites [Gustin et al., 2015]. This was followed by rapid depletion of surface $\mathrm{O}_{3}$ at these sites through deposition and titration, the latter playing larger roles at Joe Neal and Jerome Mack where there are 


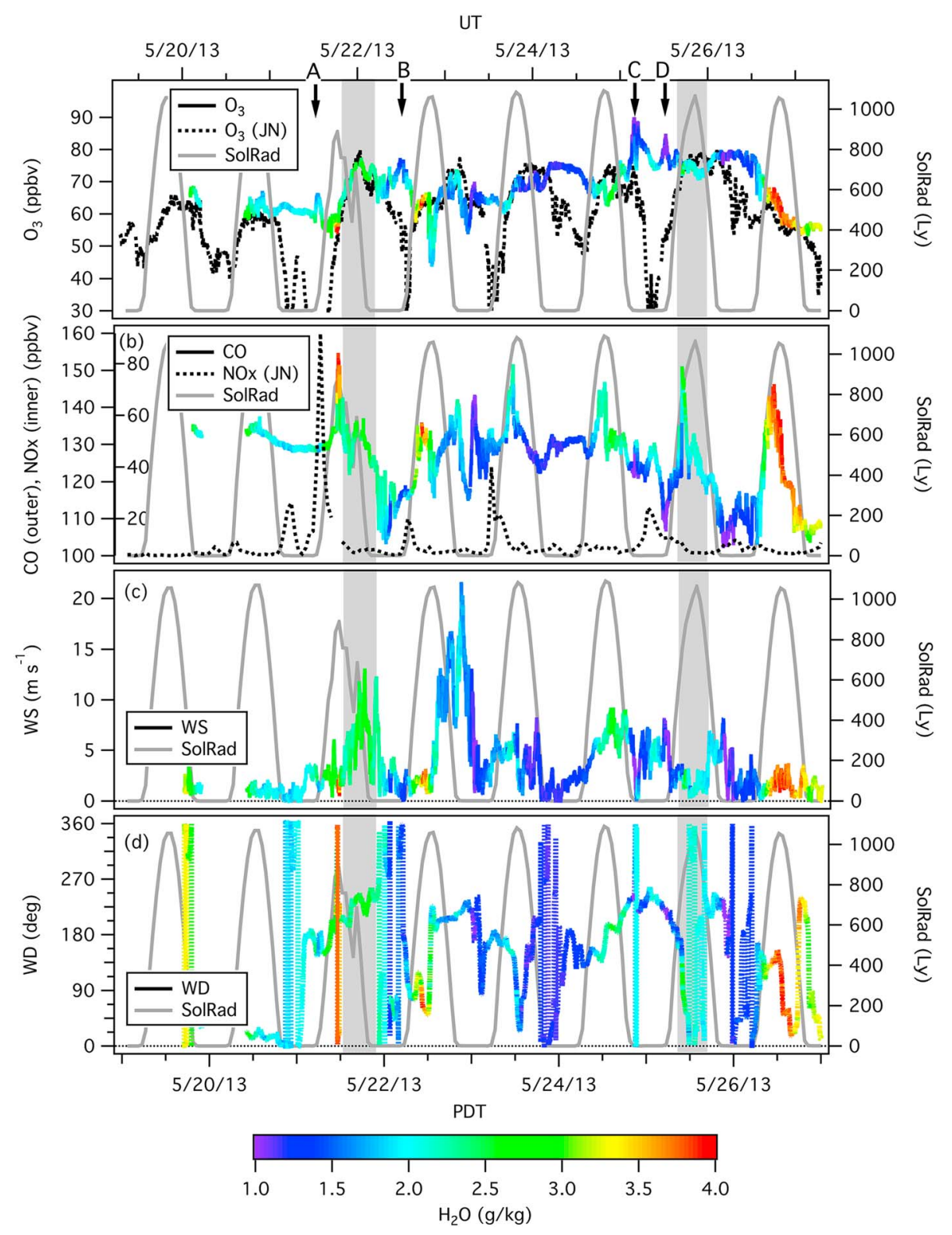

Figure 11. Time series of the in situ (a) $\mathrm{O}_{3}$, (b) $\mathrm{CO}$, (c) wind speed, and (d) wind direction measured at the summit of Angel Peak (winds less than $1 \mathrm{~m} \mathrm{~s}^{-1}$ are dotted). The Angel Peak measurements have been colorized by specific humidity. The dotted black curves in Figures $11 \mathrm{a}$ and $11 \mathrm{~b}$ show the $\mathrm{O}_{3}$ and $\mathrm{NO}_{x}$ measurements, respectively, from the Joe Neal monitor. The gray curves show the solar radiation from the nearby Spring Mountain Youth Camp (SMYC), and the gray bands highlight the two NAAQS exceedance events in Clark County.

more local sources of $\mathrm{NO}_{\mathrm{x}}$ (cf. Figure 11). Some depletion also occurred at Jean, which lies along the I-15 corridor. Figures 10a and 10b show that the depletion was particularly strong in the LVV during the night of 20-21 May. The nocturnal losses were smaller at Death Valley National Park, which has fewer sources of $\mathrm{NO}_{\mathrm{x}}$.

The strong afternoon correlations between the ozone concentrations measured in and around the LVV and those measured at Angel Peak are consistent with downward mixing of ozone from the free troposphere into the lower-lying areas of Clark County. However, the reverse process, including transport from Southern California, can also occur. Transport within the LVV is dominated by thermally driven diurnal flow patterns in summer, particularly the southwesterly regional-scale plains-mountain flows and mesoscale valley and slope flows [Stewart et al., 2002]. The LVOS measurements clearly showed that daytime upslope flows frequently transported ozone and other pollutants to Angel Peak via the Kyle Canyon drainage in June 
[Langford et al., 2015b]. These flows were much weaker in May, however, and were overwhelmed by the southerly to southwesterly synoptic winds associated with the passing upper level disturbances during the first week of the measurement campaign (cf. Figures 11c and 11d). Furthermore, although upslope flow could potentially account for the close correspondence between the afternoon $\mathrm{O}_{3}$ concentrations measured at Angel Peak and those at Joe Neal, it can less easily explain the correspondence with Palo Verde, which is separated from Kyle Canyon by the La Madre Mountains, or with Jean, and Death Valley National Park, which lie well outside the LVV. The Death Valley National Park monitor would have exceeded the 70 ppbv NAAQS on both 24 May (74 ppbv) and 25 May (73 ppbv).

Each of the Clark County monitors measured relatively high ozone every afternoon from 21 to 25 May. Four of the 11 regulatory monitors in Clark County, including Jean, Palo Verde, and Joe Neal, exceeded the 75 ppbv NAAQS with an MDA8 of 76 ppbv on 25 May, as did the monitor in Great Basin National Park (not shown). The monitor at Jean also exceeded the 75 ppbv NAAQS on 21 May (78 ppbv). The AM3 analyses suggest that this exceedance, together with that at the nearby Mojave National Preserve (see below), may have been due in part to low-level transport from the SoCAB. Transport from the Los Angeles Basin cannot explain the highozone concentrations measured above Angel Peak, however, although lofting of ozone and other pollutants into the lower free troposphere above the San Bernardino and San Gabriel Mountains does become significant in July and August [Langford et al., 2010]. Nine of the Clark County monitors would have exceeded the 70 ppbv NAAQS on both 21 and 25 May, with three and five monitors also exceeding that threshold on 22 and 23 May, respectively. To put these high concentrations in perspective, the monitor at Jean exceeded the 75 ppbv NAAQS only 3 times (including 21 and 25 May) in all of 2013 with the third exceedance taking place on 4 May following the occurrence of a stratospheric intrusion and associated wildfire in Southern California [Langford et al., 2015a]. The Jean monitor would have exceeded the 70 ppbv NAAQS for a total of 8 days in 2013 with 7 of those days occurring in May.

\section{Entrainment by the Convective Boundary Layer}

\subsection{Strong Entrainment: 21 and 25 May}

The Angel Peak measurements from 21 May, the first ozone exceedance day, are shown in more detail in Figure 12 along with the measurements from the preceding day. Figure 12a shows an expanded view of the time-height curtain plots for 20 and 21 May, together with the normalized SMYC solar radiation and NARR and VEF mixed layer heights. Figure $12 \mathrm{~b}$ displays time series of the surface $\mathrm{O}_{3}$ and $\mathrm{CO}$, together with the $\mathrm{O}_{3}$ from the Joe Neal monitor (the Jean and Jerome Mack measurements are omitted for clarity); the green points show the column ( 0 to $2 \mathrm{~km}$ agl) mean $\mathrm{O}_{3}$ mixing ratios from the TOPAZ measurements. Figure $12 \mathrm{c}$ shows the ambient temperature and specific humidity and Figure $12 \mathrm{~d}$ the wind speed and direction.

The 20 May curtain plot shows a well-defined high-ozone layer approximately $500 \mathrm{~m}$ thick and roughly $1500 \mathrm{~m}$ above the top of the NARR boundary layer. A region of weakly enhanced aerosol backscatter (not shown) consistent with long-range transport was detected along the bottom edge of the ozone layer. Winds were weak at the summit, and the top of the NARR mixed layer was just under $3000 \mathrm{~m}$ asl. The absence of a CO spike in the late morning shows that the top of the boundary layer did not reach the summit on this day. The curtain plot appears to show some descent from the layer to the summit in the midafternoon and the column and surface measurements converged briefly around 1500 PDT, but the enhancement in surface ozone was less than 5 ppbv and did not reach Joe Neal where the concentrations remained 2-3 ppbv lower than those measured at Angel Peak.

The 00 UT 22 May (17 PDT on 21 May) VEF sounding (Figure 13) shows very dry air between 4 and $6 \mathrm{~km}$ asl above a deep mixed layer ( $4000 \mathrm{~m}$ asl) with a very deep entrainment zone. The surface measurements at the summit (Figure 12) showed the characteristic wind shift and spike in $\mathrm{CO}$ and $\mathrm{H}_{2} \mathrm{O}$ associated with the appearance of the mixed layer cap at about 1130 PDT. Surface winds were strong, rotating from south to west as the upper level trough passed overhead, and the SMYC solar radiation decreased as thick clouds associated with the passing cold front moved overhead above $6 \mathrm{~km}$ asl. The TOPAZ curtain plot shows strong mixing in the afternoon, and convergence (to within \pm 1 ppbv) of the Joe Neal, Angel Peak, and TOPAZ column $\mathrm{O}_{3}$ indicates that deep vigorous mixing extended to at least $4000 \mathrm{~m}$ asl. 

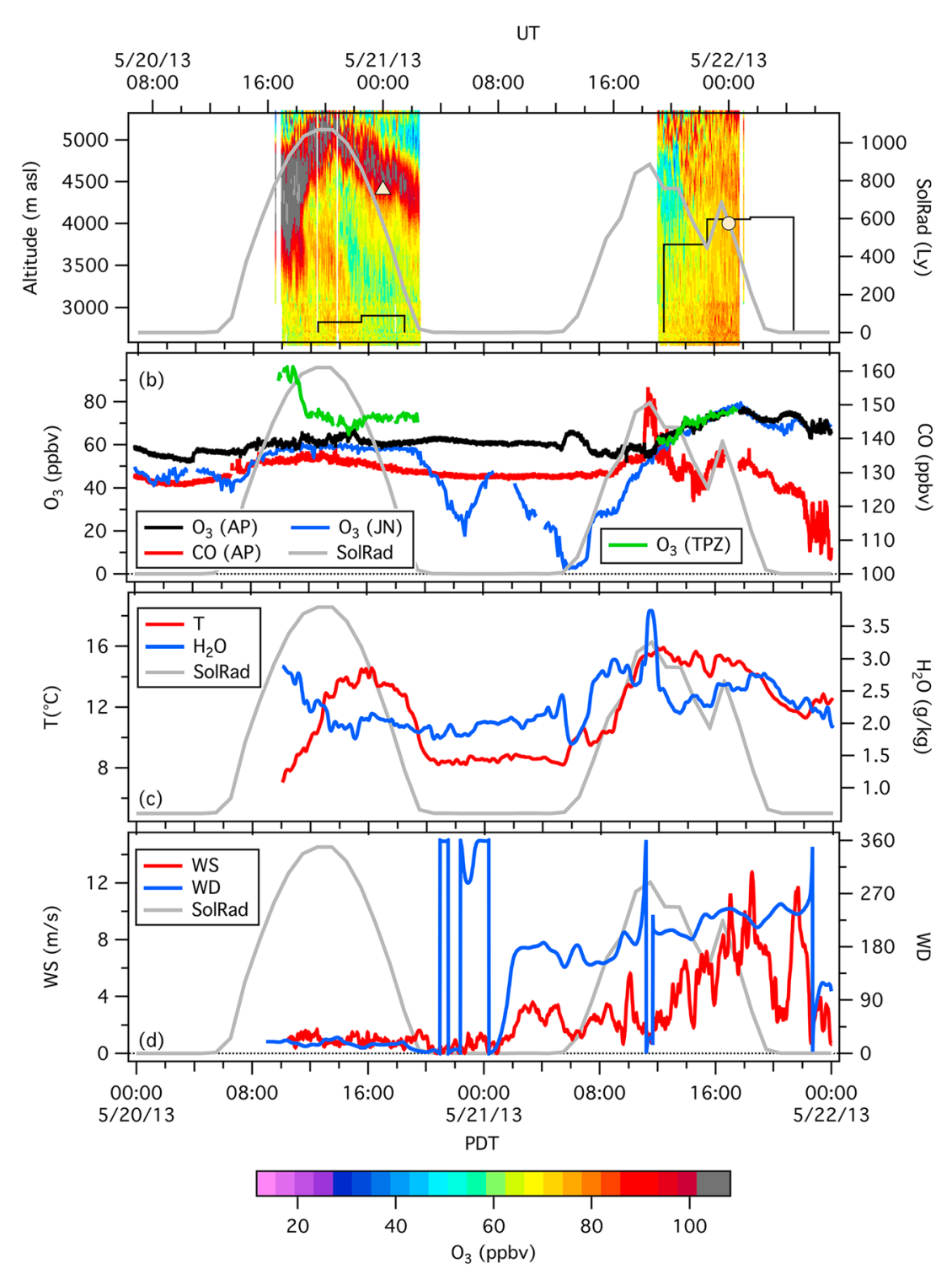

Figure 12. (a) Enlarged view of the TOPAZ measurements from 20-21 May 2013. (b) Time series of the corresponding surface $\mathrm{O}_{3}$ (black) and $\mathrm{CO}$ (red) measurements from Angel Peak and surface $\mathrm{O}_{3}$ from Joe Neal (blue). The green points represent the mean column ( 0 to $2000 \mathrm{~m}$ agl) $\mathrm{O}_{3}$ from TOPAZ. (c) Temperature and specific humidity at Angel Peak. (d) Wind speed and direction at Angel Peak.

Figure 14 is similar to Figure 12 but shows the measurements from 24 to 25 May, when TOPAZ was operated for a continuous $20 \mathrm{~h}$ interval throughout the night. The curtain plot is rich in structure with inclusions of lower-ozone air embedded in the descending tongue of high ozone. High ozone was present between 4500 and $5000 \mathrm{~m}$ asl in the first profiles at about 13 PDT and descended to the top of the VEF mixed layer ( $4 \mathrm{~km}$ asl) by 17 PDT. The VEF sounding in Figure 15 appears similar to the 22 May sounding in Figure 13, but the arrival of the high-ozone layer in the late afternoon when the convective boundary layer was beginning to subside limited the degree of entrainment and little ozone reached the valley. The descending ozone reached the summit in the early evening with turbulent mixing driven by the strong south to southwesterly synoptic winds. Discrete ozone filaments continued to appear throughout the night until the last TOPAZ measurements at 0630 PDT on 25 May. Although there were no TOPAZ measurements later in the day, the surface $\mathrm{O}_{3}$ at Angel Peak remained between 70 and 80 ppbv for the next $24 \mathrm{~h}$ (with $\mathrm{CO}$ and $\mathrm{H}_{2} \mathrm{O}$ declining during the night of 25-26 May). 

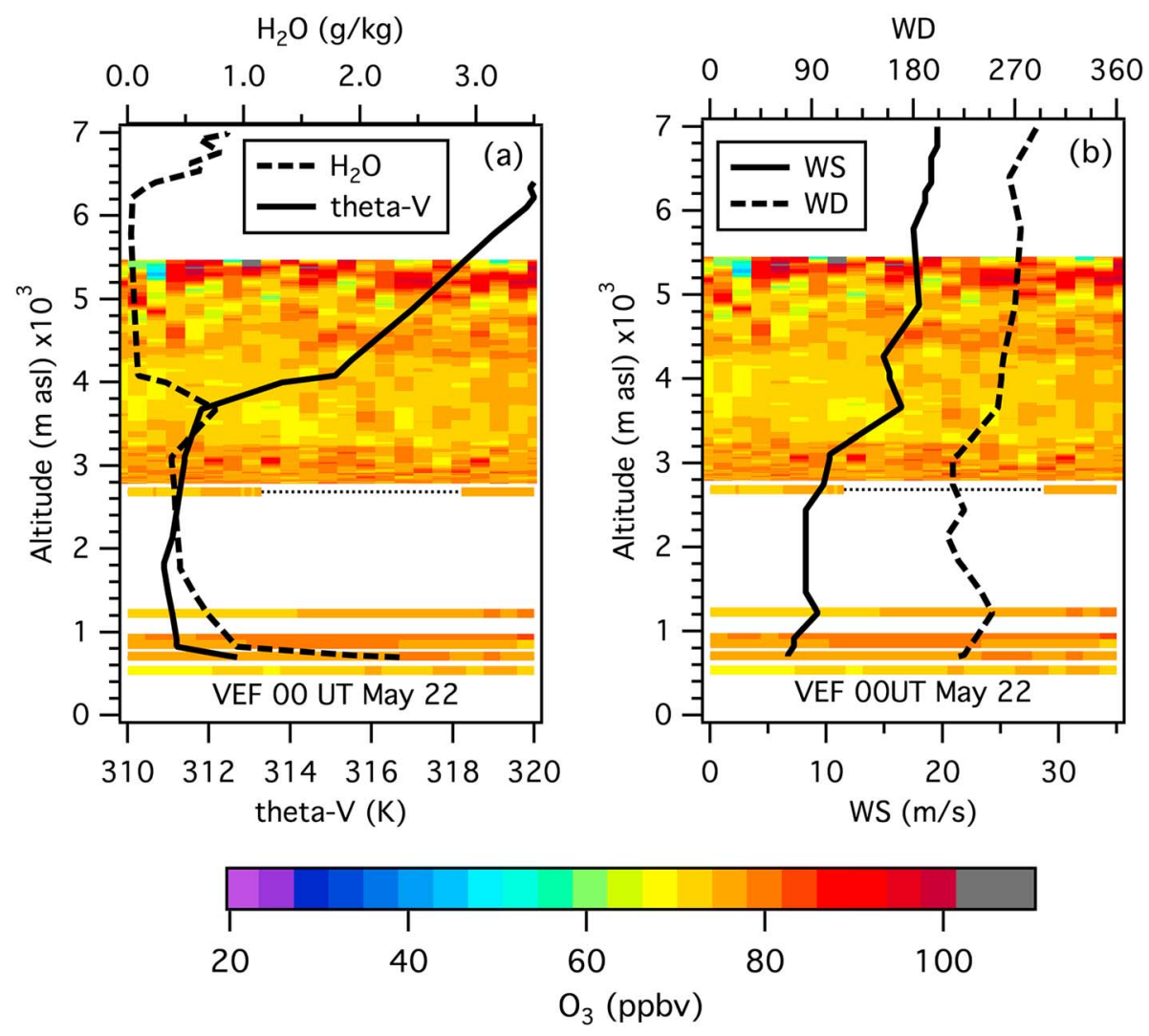

Figure 13. (a) Virtual potential temperature and specific humidity and (b) wind speed and direction profiles from the 00 UT 22 May afternoon (17 PDT 21 May) VEF sounding. The superimposed curtain plots show the TOPAZ measurements from 16 to 18 PDT that bracket the sounding. The horizontal bars near the middle and bottom show the corresponding surface measurements as in Figure 10.

The UT/LS air presumably continued to descend below the summit of Angel Peak during the night, but did not reach the LVV, which was capped by a strong nocturnal boundary layer. This air was rapidly entrained the following morning, however, with the Angel Peak and Joe Neal time series converging around 75 ppbv near 10 PDT when the spike in $\mathrm{CO}$ and $\mathrm{H}_{2} \mathrm{O}$ and wind shift showed that the mixed layer had reached the summit. Concentrations remained similar throughout the day and into the evening until the nocturnal inversion layer formed. The persistence of the high surface ozone at Angel Peak shows that subsiding UT/LS air covered a very large area; advection at $2 \mathrm{~m} \mathrm{~s}^{-1}$ for $36 \mathrm{~h}$ (cf. Figure 11) implies a minimum horizontal dimension of at least $250 \mathrm{~km}$. Ozone was also elevated at the central and southern NVROI sites including Echo Peak on the night of 24-25 May, and the 25th was also an exceedance day at the Great Basin National Park [Fine et al., 2015a].

\subsection{Weak Entrainment: 19 and 26 May}

The deep entrainment and downward mixing of stratospheric or transported ozone that led to the NAAQS exceedances on 21 and 25 May contrast sharply with the observations from 19, 20, and 26 May. TOPAZ also detected high-ozone layers below $5 \mathrm{~km}$ asl on those days, but the much higher definition of these layers shows that there was relatively little entrainment, and low concentrations measured by the LVV surface monitors indicate that transport to the surface in Clark County was negligible. The reasons for this can be seen from Figure 16, which is similar to Figures 12 and 14, but shows the 00 UT (17 PDT) VEF soundings from 20 and 27 May.

Figures 16a and 16b show that the high-ozone layer above Angel Peak on 19 May was aligned along the bottom of a strong northwesterly jet composed of extremely dry air consistent with descent from the lower stratosphere. These observations are consistent with the curving filament of high ozone seen to the east of 

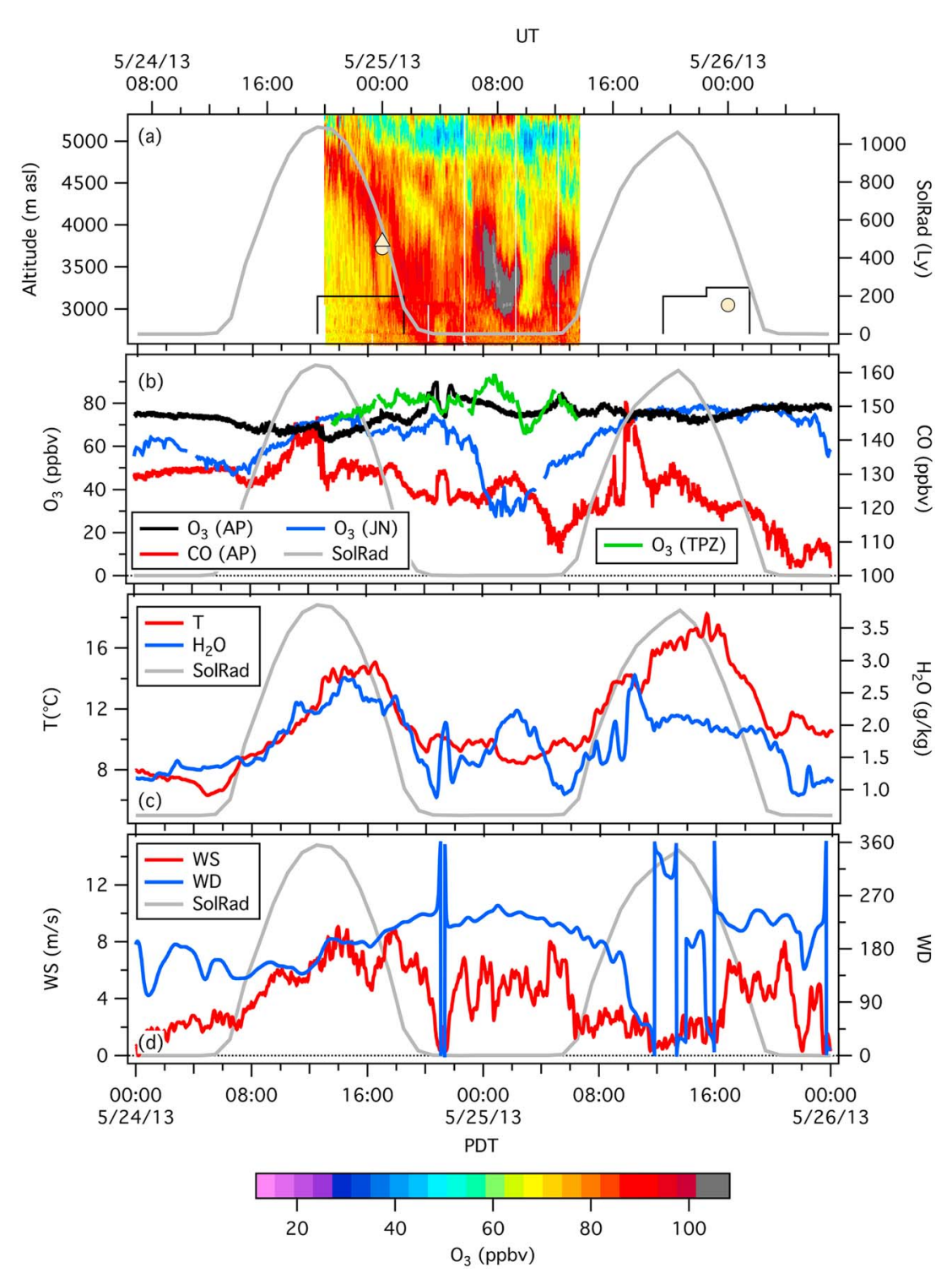

Figure 14. (a) Enlarged view of the TOPAZ measurements from 24-25 May 2013. (b) Time series of the corresponding surface $\mathrm{O}_{3}$ (black) and $\mathrm{CO}$ (red) measurements from Angel Peak and surface $\mathrm{O}_{3}$ from Joe Neal (blue). The green points represent the mean column ( 0 to $2000 \mathrm{~m}$ agl) $\mathrm{O}_{3}$ from TOPAZ. (c) Temperature and specific humidity at Angel Peak. (d) Wind speed and direction at Angel Peak.

Angel Peak in the RAQMS and FLEXPART analyses from 12 UT (05 PDT) on 20 May. Strong velocity shear beneath the jet produced some turbulent mixing of the ozone layer into the top of the boundary layer, but the strong synoptic flow also forced a dry, cold northerly jet up the valley, creating a stable potential temperature profile that inhibited downward mixing of the ozone into the valley. The surface measurements at Angel Peak did not begin until later that evening, but the concentrations remained relatively low ( 60 ppbv) in the LVV.

Surface concentrations were even lower on 26 May when the VEF sounding showed a much shallower boundary layer $(\sim 3 \mathrm{~km}$ asl) that simply did not reach the high ozone aloft (Figures $16 \mathrm{c}$ and 16d). Ozone remained low at Angel Peak as well as in the LVV and surrounding Clark County. The high specific humidity in both the boundary layer and the air immediately above is consistent with the marine boundary layer influence inferred from the surface measurements, and the high aerosol backscatter (not shown) and specific humidity suggest that the high-ozone layer near $5 \mathrm{~km}$ asl was primarily composed of transported pollution. 

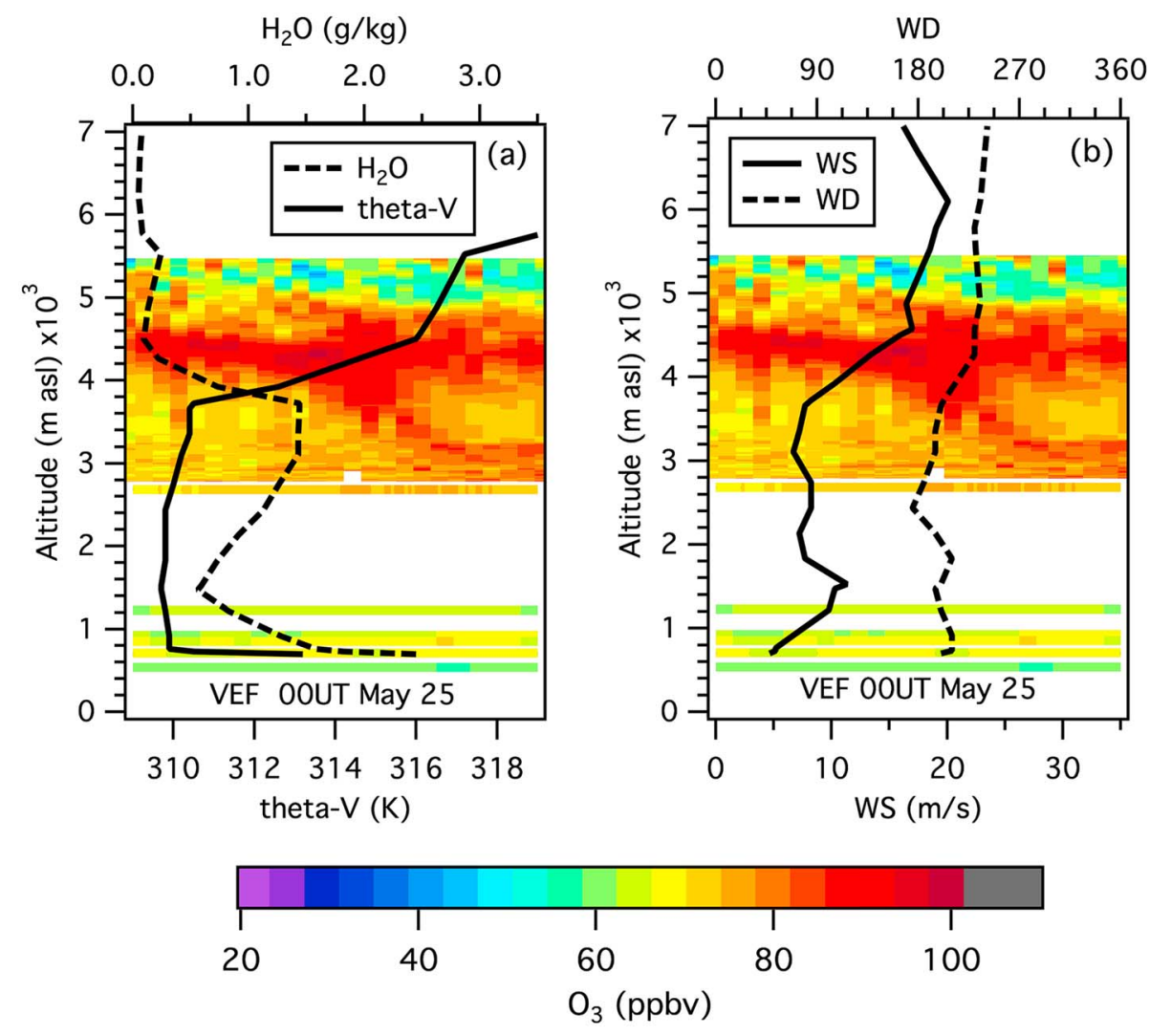

Figure 15. Same as in Figure 13 but for 00 UT on 25 May (17 PDT on 24 May).

\section{Impact on Regional Surface Ozone}

Figure 17 displays maps of the southwestern U.S. with the surface monitors color coded to reflect the MDA8 ozone concentrations using a modified version of the 2008 Air Quality Index color scheme. Concentrations considered "good" ( $<60$ ppbv) are shown in green and those deemed "moderate" (60 to $70 \mathrm{ppbv}$ ) under both the 2008 and 2015 NAAQS in yellow. Those concentrations considered moderate under the 2008 NAAQS but in exceedance under the 2015 NAAQS are colored yellow-orange. Concentrations designated as "unhealthy for sensitive groups" (76 to $95 \mathrm{ppbv}$ ) and exceeding the $75 \mathrm{ppbv}$ NAAQS are colored orange. Measurements bracketing the two Clark County exceedance days ( 21 and 25 May) are shown. These distributions appear qualitatively similar to the AM3-calculated total ozone concentrations in Figures 7 and 8.

The first exceedance day in Clark County was preceded by moderate (yellow) ozone across much of California and southwestern Nevada on 20 May, with five monitors near the San Gabriel and San Bernardino Mountains in the SoCAB also exceeding the 75 ppbv NAAQS. The highest ozone in the SoCAB is often found in this area as $\mathrm{NO}_{x}$ and $\mathrm{VOC}$ precursors emitted near the coast are blown inland by the sea breeze and accumulate near the foothills [Langford et al., 2010]. This cluster is consistent with the compact CO hot spot in the $300 \mathrm{~K}$ RAQMS distributions of Figure S1, and the hot spot in the AM3 "total minus ST" ozone results for 21 May in Figure 7. Sixteen of the AQS monitors in Southern California and Nevada exceeded the 75 ppbv NAAQS on 21 May with the highest MDA8 concentrations ( $90 \mathrm{ppbv}$ ) measured on the periphery of the SoCAB and in the Mojave desert. Somewhat lower concentrations ( $70-80 \mathrm{ppbv}$ ) were measured within the Basin itself. These observations are consistent with transport of photochemically produced ozone from the SoCAB through the Cajon Pass and into the high desert; the gradient along the I-15 corridor through Barstow ( 84 ppbv), the Mojave National Preserve ( $86 \mathrm{ppbv})$, and Jean (78 ppbv) indicates that some of this ozone may have also reached the Las Vegas Valley. The RAQMS and FLEXPART models also suggest that there may have been some Asian pollution mingled with the descending UT/LS air, a result consistent with the $\mathrm{CO}^{-} \mathrm{O}_{3}$ correlations at Angel Peak shown in Figure S4b. 

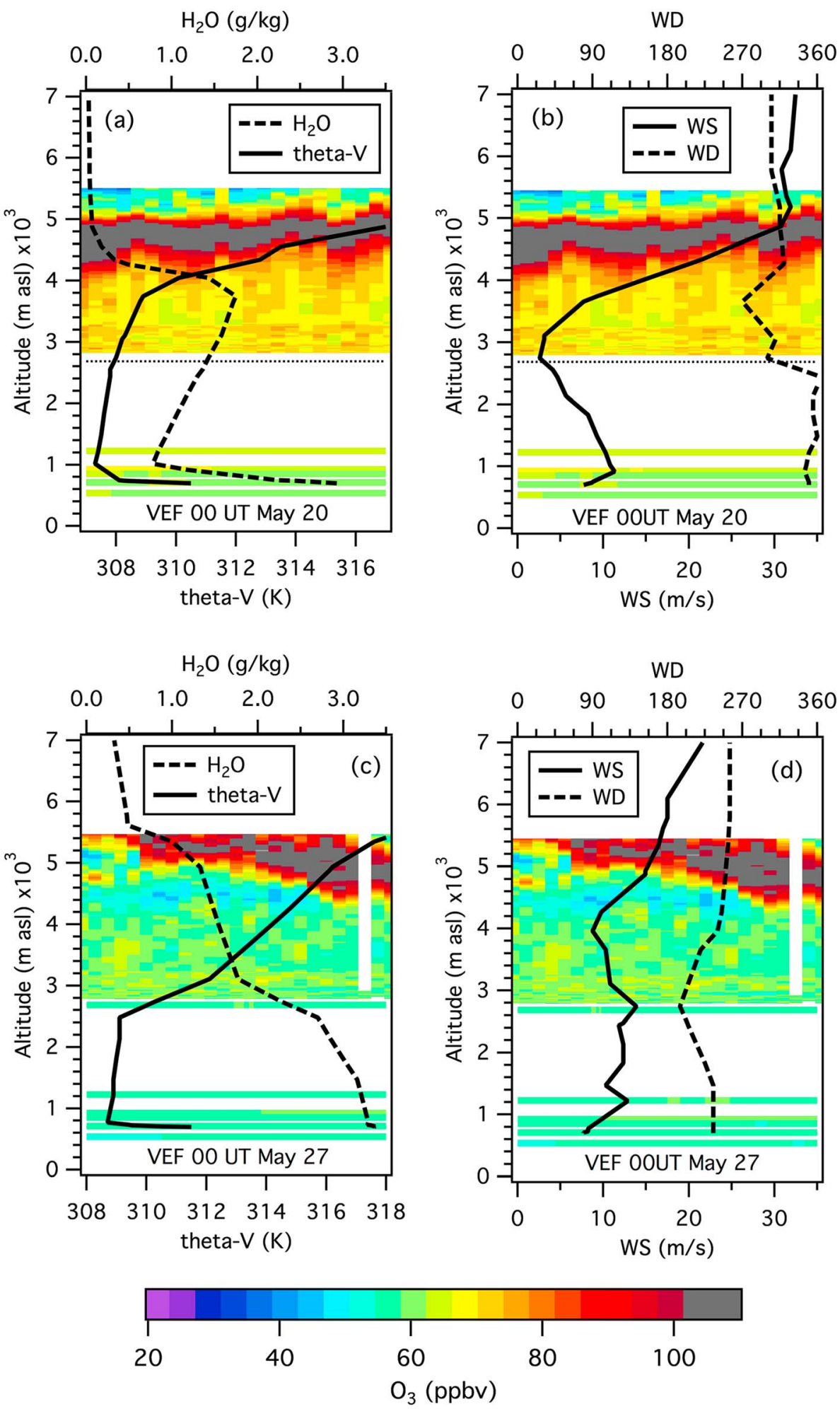

Figure 16. Same as in Figure 13 but for ( $a$ and b) 00 UT on 20 May (17 PDT on 19 May) and (c and d) 00 UT on 27 May (17 PDT on 26 May). 

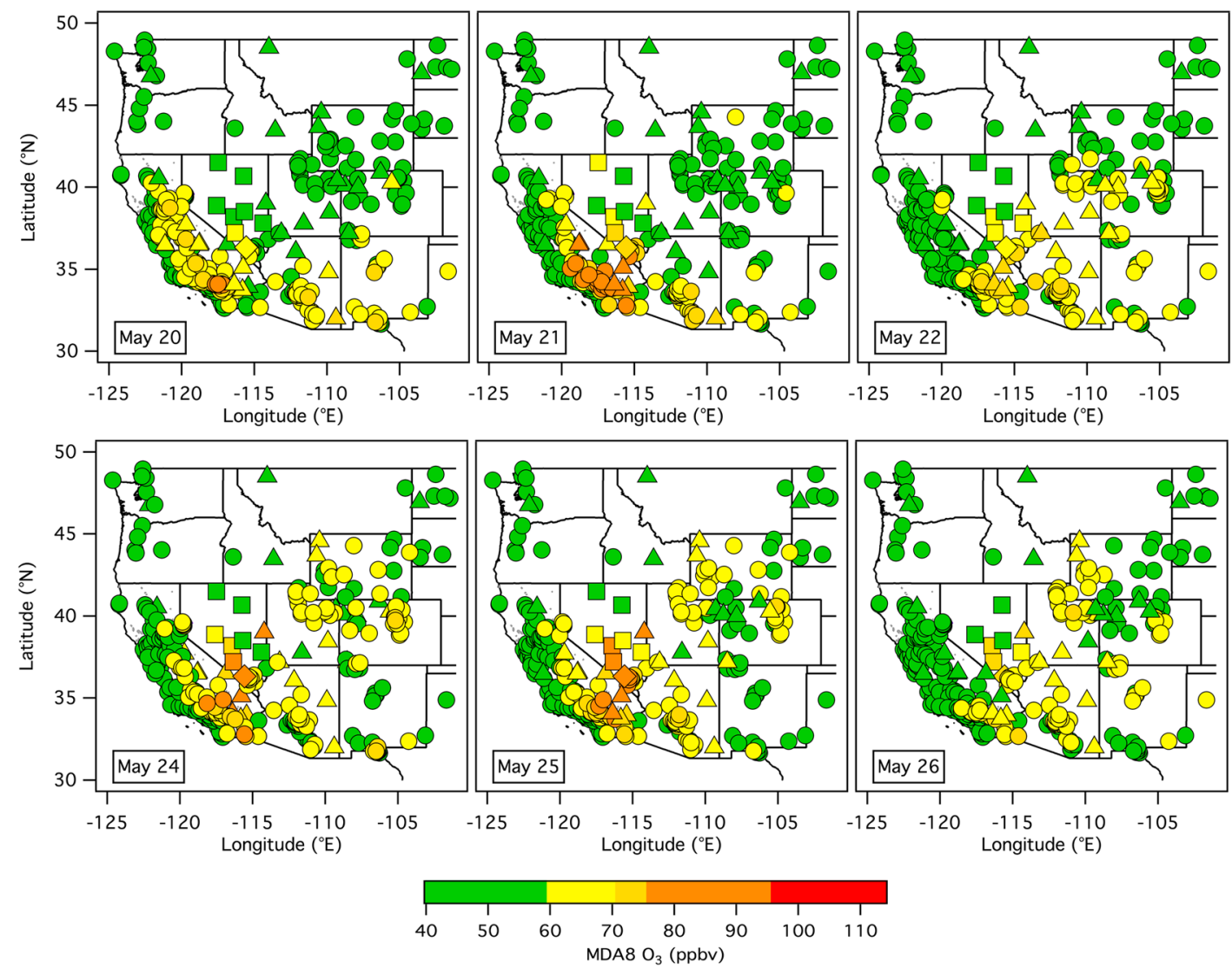

Figure 17. Regional maps showing the ozone measured by surface monitors operational on (top) $20-22$ and (bottom) 24-26 May. The symbols are the same as in Figure 2. The monitors are color coded to reflect a modified version of the 2008 Air Quality Index (AQI) scale with good (0-59 ppbv; green), moderate 2015 (60-70 ppbv; yellow), moderate 2008 (70-75 ppbv; yellow-orange), unhealthy for sensitive groups (76-95 ppbv; orange), and unhealthy (96-115 ppbv; red) values.

There were no MDA8 concentrations greater than the 75 ppbv NAAQS in the South Coast Air Basin (SoCAB) on 24-26 May, although there were several exceedances in the adjacent Salton Sea and Mojave Desert Air Basins including Barstow (78ppbv) and the Mojave National Preserve (76ppbv). The NAAQS was also exceeded by the Angel Peak monitor and by several of the NVROI monitors [Fine et al., 2015a] on both 24 and 25 May and by four of the Clark County monitors on 25 May. These exceedances are consistent with the large influx of stratospheric air seen by all three models, with no clear evidence for the modest influxes of pollution from Asia and Los Angeles suggested by the FLEXPART tracers (Figures S2 and S3) in the $\mathrm{CO}-\mathrm{O}_{3}$ correlations at Angel Peak.

\section{Summary}

The 2013 Las Vegas Ozone Study provided an unprecedented look at the influence of STT and associated long-range transport of pollution from Asia on surface ozone in the southwestern United States. Our analysis suggests that significant amounts of ozone-rich stratospheric air and, in some cases, mingled Asian pollution was entrained into the convective boundary layer above the LVV for five consecutive days from 21 to 25 May 2013. This descending ozone affected surface concentrations at both low- and high-elevation sites, adding to the existing regional background (including ozone transported from the SoCAB) and that formed locally within Clark County, NV. The net effect was to push the MDA8 concentrations above the 2008 NAAQS of 75 ppbv at the Jean monitor (78 ppbv) on 21 May and at the Jean (76 ppbv), Joe Neal (76 ppbv), Palo Verde (76 ppbv), and Paul Meyer (76 ppbv) monitors on 25 May. The 2008 NAAQS was also exceeded at the Great Basin National Park (76 ppbv; cf. Figure 2) on 25 May. Additional exceedances would have occurred if the new 70 ppbv NAAQS had been in effect. 


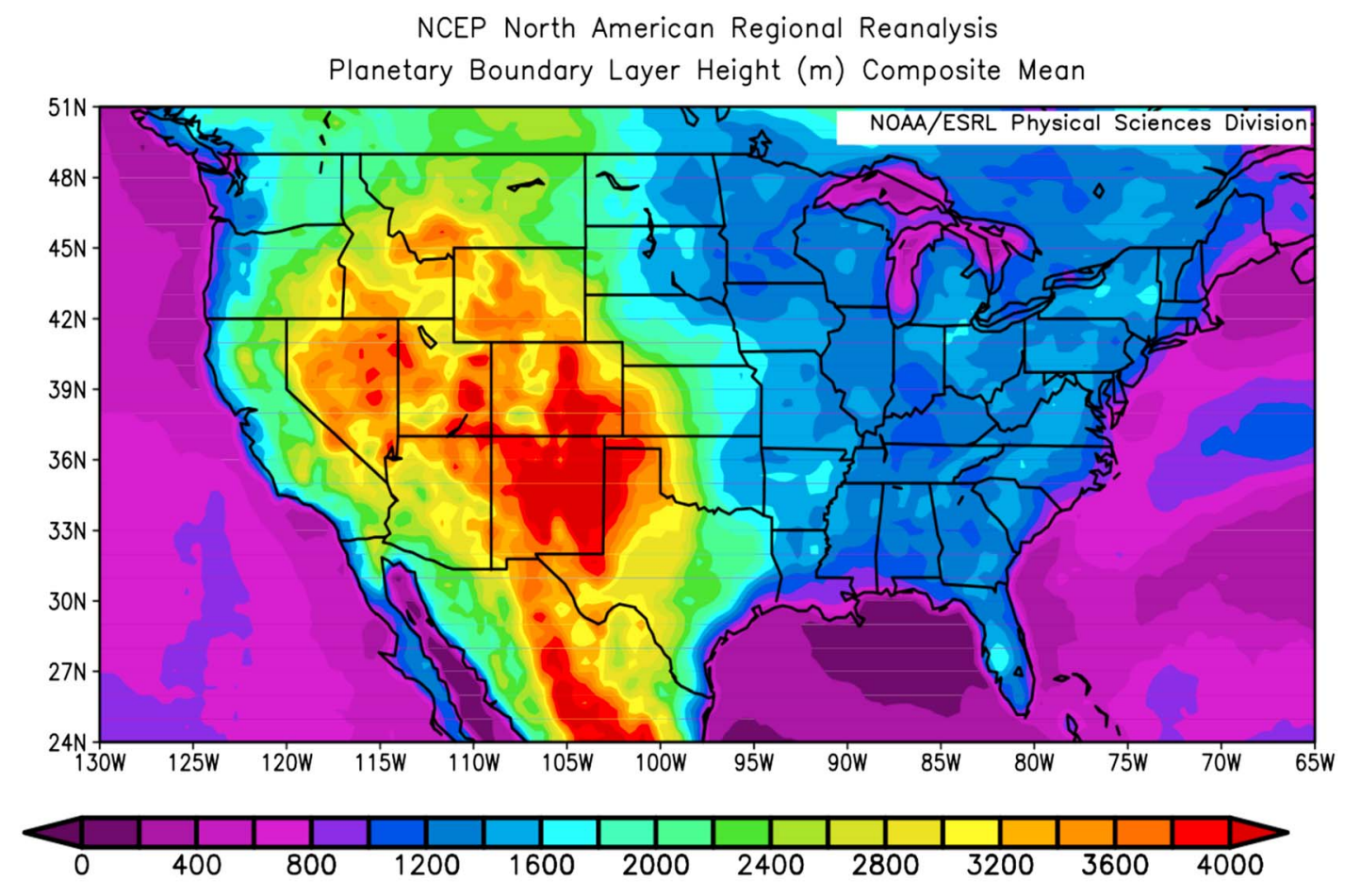

May 19-26, 2013 (21-00 UT)

Figure 18. Mean afternoon ( 21 to 00 UT) boundary layer heights from the NARR for the 19-26 May 2013 study period (http://www.esrl.noaa.gov/psd/data/narr/).

Our results do not imply that STT and transported pollution were the primary sources of surface ozone on the two exceedance days, but they do show that the contributions were significant. The AM3 and FLEXPART analyses suggest that the contributions of STT to the MDA8 surface ozone at Angel Peak were on the order of 20-40 ppbv on both 21 and 25 May, with an additional contribution of up to $10 \mathrm{ppbv}$ from long-range transport on 21 May. The mingling of regional pollution with the Asian pollution and stratospheric air on 21 May makes it more difficult to quantify the STT contribution at lower-elevation sites like Jean. Nevertheless, since the measurements there exceeded the NAAQS by only 1-3 ppbv on both days, we can conclude that neither exceedance would have occurred without the contributions from STT and long-range transport.

The uncertainties inherent in using relatively coarse spatial resolution global models and localized measurements to connect the surface concentrations at a fixed point to synoptic-scale phenomena like stratosphereto-troposphere transport and long-range transport underscores the need for nested high-resolution regional models and more extensive observations including coordinated surface, remote sensing, and aircraft measurements. All of these tools will be employed in a follow-up field study (Fires, Asian, and Stratospheric Transport-Las Vegas Ozone Study) planned for May-June 2017.

Our findings support previous climatological studies [e.g., Skerlak et al., 2014], which found that deep stratospheric intrusions occur frequently in the southwestern U.S. and Intermountain West during late spring and early summer, particularly during La Niña years when the mean position of the polar front jet lies near the $U$. S.-Canadian border [Lin et al., 2015a]. Our study suggests that turbulent entrainment by the unusually deep convective boundary layers of the southwestern U.S. (cf. Figure 18) are more likely to bring this descending lower stratospheric air and entrained pollution to the surface than in other parts of the country, contributing to the springtime surface ozone maximum seen in the Southwest. These deep mixed layers can potentially capture stratospheric air and Asian pollution that has passed over California and the Sierra Nevada Mountains to increase surface ozone at both high and low elevations, affecting both remote areas like the Death Valley, Grand Canyon, and Great Basin National Parks [Gustin et al., 2015] and highly populated urban centers like Las Vegas and Phoenix. 


\section{Acknowledgments}

The NOAA ESRL lidar operations were funded by the NOAA Health of the Atmosphere and Climate Programs and the NASA-sponsored Tropospheric Ozone Lidar Network (TOLNet; http:// www-air.larc.nasa.gov/missions/ TOLNet/). The Las Vegas Ozone Study (LVOS) was funded primarily by the Clark County Department of Air Quality under contract CBE 602948-13. The lidar data are available at http://www.esrl. noaa.gov/csd/groups/csd3/measurements/lvos/. The authors would like to thank Zheng Li, Mickey Turner, Dennis Ransel, and the other staff of the Clark County Department of Air Quality for their assistance and hospitality during LVOS. We are grateful to John Vimont of the U.S. National Park Service and Jessica Ward of Air Resource Specialists, Inc. for providing the $1 \mathrm{~min}$ NPS ozone data and to John Holloway for the assistance with the $\mathrm{CO}$ measurements. We also thank Owen Cooper of NOAA/ESRL and CIRES for providing the water vapor imagery. Meiyun Lin is supported by funding from NASA's Atmospheric Composition Campaign Data Analysis and Modeling program (NNX14AR47G) and NASA's Air Quality Applied Sciences Team (NNX12AF15G). The Nevada Rural Ozone Initiative was supported by the Nevada Division of Environmental Protection under contract DEP 11-006. The RAQMS modeling efforts were supported by the NOAA GOES-R Program Office, the NASA Atmospheric Modeling and Analysis Program, and the NASA Applied Science Program. We would also like to thank the reviewers for their helpful suggestions. The views, opinions, and findings contained in this report are those of the author(s) and should not be construed as an official National Oceanic and Atmospheric Administration or U.S Government position, policy, or decision.

\section{References}

Akritidis, D., P. Zanis, I. Pytharoulis, A. Mavrakis, and T. Karacostas (2010), A deep stratospheric intrusion event down to the Earth's surface of the megacity of Athens, Meteor. Atmos. Phys., 109, 9-18, doi:10.1007/S00703-010-0096-6.

Altmanspacher, W., and R. Hartmannsgruber (1973), On extremely high values of ozone near the ground at the observatory Hohenpeissenberg, Pageoph, 106-108, doi:10.1007/BF00881062.

Alvarez, R. J., II, et al. (2011), Development and application of a compact, tunable, solid-state airborne ozone lidar system for boundary layer profiling, J. Atmos. Oceanic Tech., 28, 1258-1272, doi:10.1175/Jtech-D-10-05044.1.

Ambrose, J. L., D. R. Reidmiller, and D. A. Jaffe (2011), Causes of high $\mathrm{O}_{3}$ in the lower free troposphere over the Pacific Northwest as observed at the Mt. Bachelor Observatory, Atmos. Environ., 45, 5302-5315, doi:10.1016/j.atmosenv.2011.06.056.

Brioude, J., et al. (2007), Mixing between a stratospheric intrusion and a biomass burning plume, Atmos. Chem. Phys., 7, 4229-4235

Browell, E. V., E. F. Danielsen, S. Ismail, G. L. Gregory, and S. M. Beck (1987), Tropopause fold structure determined from airborne lidar and in situ measurements, J. Geophys. Res., 92, 2112-2120, doi:10.1029/JD092iD02p02112.

Cooper, O. R., A. O. Langford, D. D. Parrish, and D. W. Fahey (2015), Challenges of a lowered US ozone standard, Science, 348(6239), 1096-1097, doi:10.1126/science.aaa5748.

Cooper, O. R., et al. (2004), A case study of trans-Pacific warm conveyor belt transport: The influence of merging airstreams on trace gas import to North America, J. Geophys. Res., 108(D23S08), doi:10.1029/2003JD003624.

Cooper, O. R., et al. (2010), Increasing springtime ozone mixing ratios in the free troposphere over western North America, Nature, 463, 344-348.

Danielsen, E. F. (1968), Stratosphere-tropospheric exchange based upon radioactivity, ozone, and potential vorticity, J. Atmos. Sci., 25, 502-518.

Danielsen, E. F., R. S. Hipskind, S. E. Gaines, G. W. Sachse, G. L. Gregory, and G. F. Hill (1987), Three-dimensional analysis of potential vorticity associated with tropopause folds and observed variations of ozone and carbon monoxide, J. Geophys. Res., 92, 2103-2111, doi:10.1029/ JD092iD02p02103.

Dempsey, F. (2014), Observations of stratospheric O-3 intrusions in air quality monitoring data in Ontario, Canada, Atmos. Environ., 98, 111-122, doi:10.1016/j.atmosenv.2014.08.024.

Emanuel, K. A., and M. Zivkovic-Rothman (1999), Development and evaluation of a convective scheme for use in climate models, J. Atmos. Sci., 56, 1766-1782.

Fine, R., M. B. Miller, J. Burley, D. A. Jaffe, R. B. Pierce, M. Y. Lin, and M. S. Gustin (2015a), Variability and sources of surface ozone at rural sites in Nevada, USA: Results from two years of the Nevada Rural Ozone Initiative, STOTEN, 530, 471-482, doi:10.1016/j.scitotenv.2014.12.027.

Fine, R., M. B. Miller, E. L. Yates, and M. S. Gustin (2015b), Investigating the influence of long-range transport on surface $\mathrm{O}_{3}$ in $\mathrm{Nevada}$, USA using observations from multiple measurement platforms, STOTEN, 530-531, 493-504, doi:10.1016/j.scitotenv.2015.03.125.

Fiore, A. M., J. T. Oberman, M. Y. Lin, L. Zhang, O. E. Clifton, D. J. Jacob, V. Naik, L. W. Horowitz, J. P. Pinto, and G. P. Milly (2014), Estimating North American background ozone in U.S. surface air with two independent global models: Variability, uncertainties, and recommendations, Atmos. Environ., 96, 284-300, doi:10.1016/j.atmosenv.2014.07.045.

Gravelle, C. M., J. R. Mecikalski, W. E. Line, K. M. Bedka, R. A. Petersen, J. M. Sieglaff, G. T. Stano, and S. J. Goodman (2016), Demonstration of a GOES-R satellite convective toolkit to "Bridge the gap" between severe weather watches and warnings an example from the 20 May 2013 Moore, Oklahoma, Tornado outbreak, Bull. Am. Meteorol. Soc., 97(1), 69-84, doi:10.1175/BAMS-D-14-00054.1.

Gustin, M. S., R. Fine, M. Miller, D. Jaffe, and J. Burley (2015), The Nevada Rural Ozone Initiative (NVROI): Insights to understanding air pollution in complex terrain, STOTEN, 530, 455-470, doi:10.1016/j.scitotenv.2015.03.046.

Hanna, S. R. (1982), In Applications in Air Pollution Modeling, in Atmospheric Turbulence and Air Pollution Modelling, edited by F. T. M. Nieuwstadt, H. van Dop, and D. Reidel, Publishing Company, Dordrecht, Netherlands.

Heald, C. L., et al. (2003), Asian outflow and trans-Pacific transport of carbon monoxide and ozone pollution: An integrated satellite, aircraft, and model perspective, J. Geophys. Res., 108(D24), doi:10.1029/2003JD003507.

Holloway, J. S., R. O. Jakoubek, D. D. Parrish, C. Gerbig, A. Volz-Thomas, S. Schmitgen, A. Fried, B. Wert, B. Henry, and J. R. Drummond (2000), Airborne intercomparison of vacuum ultraviolet fluorescence and tunable diode laser absorption measurements of tropospheric carbon monoxide, J. Geophys. Res., 105(D19), 24,251-24,261, doi:10.1029/2000JD900237.

Holton, J. R., P. H. Haynes, M. E. Mclntyre, A. E. Douglass, R. B. Rood, and L. Pfister (1995), Stratosphere-troposphere exchange, Rev. Geophys., 33, 403-439, doi:10.1029/95RG02097.

Horel, J., M. Splitt, L. Dunn, J. Pechmann, B. White, C. Ciliberti, S. Lazarus, J. Slemmer, D. Zaff, and J. Burks (2002), Mesowest: Cooperative mesonets in the western United States, Bull. Am. Meteorol. Soc., 83(2), 211--225, doi:10.1175/1520-0477(2002)083<0211:Mcmitw>2.3.Co;2.

Huang, M., K. W. Bowman, G. R. Carmichael, M. Lee, T. F. Chai, S. N. Spak, D. K. Henze, A. S. Darmenov, and A. M. da Silva (2015), Improved western US background ozone estimates via constraining nonlocal and local source contributions using Aura TES and OMI observations, J. Geophys. Res. Atmos., 120, 3572-3592, doi:10.1002/2014JD022993.

Jacob, D. J., J. A. Logan, and P. P. Murti (1999), Effect of rising Asian emissions on surface ozone in the United States, Geophys. Res. Lett., 26, 2175-2178, doi:10.1029/1999GL900450.

Jaffe, D. A., et al. (1999), Transport of Asian air pollution to North America, Geophys. Res. Lett., 26(6), 711-714, doi:10.1029/1999GL900100.

James, P., A. Stohl, C. Forster, S. Eckhardt, P. Seibert, and A. Frank (2003), A 15-year climatology of stratosphere-troposphere exchange with a Lagrangian particle dispersion model: 2. Mean climate and seasonal variability, J. Geophys. Res., 108, doi:10.1029/2002JD002639.

Janjić, Z. I. (1996), The Mellor-Yamada level 2.5 scheme in the NCEP Eta model., paper presented at 11th Conf. on Numerical Weather Prediction, Amer. Meteor. Soc, Norfolk, Va.

Johnson, W. B., and W. Viezee (1981), Stratospheric ozone in the lower troposphere-I. Presentation and interpretation of aircraft measurements, Atmos. Environ., 15, 1309-1323.

Kunz, H., and P. Speth (1997), Variability of near-ground ozone concentrations during cold front passages-A possible effect of tropopause folding events, J. Atmos. Chem., 28, 77-95.

Lamb, R. G. (1977), A case study of stratospheric ozone affecting ground-level oxidant concentration, J. Appl. Meteorol., 16, $780-794$.

Langford, A. O., K. C. Aikin, C. S. Eubank, and E. J. Williams (2009), Stratospheric contribution to high surface ozone in Colorado during springtime, Geophys. Res. Lett., 36, doi:10.1029/2009GL038367.

Langford, A. O., C. J. Senff, R. J. Alvarez, R. M. Banta, and R. M. Hardesty (2010), Long-range transport of ozone from the Los Angeles Basin: A case study, Geophys. Res. Lett., 37, L06807, doi:10.1029/2010GL042507.

Langford, A. O., C. J. Senff, R. J. Alvarez, R. M. Banta, R. M. Hardesty, D. D. Parrish, and T. B. Ryerson (2011), Comparison between the TOPAZ airborne ozone lidar and in situ measurements during TexAQS 2006, J. Atmos. Oceanic Tech., 28, 1243-1257, doi:10.1175/Jtech-D-10-05043.1. 
Langford, A. O., J. Brioude, O. R. Cooper, C. J. Senff, R. J. Alvarez, R. M. Hardesty, B. J. Johnson, and S. J. Oltmans (2012), Stratospheric influence on surface ozone in the Los Angeles area during late spring and early summer of 2010, J. Geophys. Res., 117, D00V06, doi:10.1029/2011JD016766.

Langford, A. O., R. B. Pierce, and P. J. Schultz (2015a), Stratospheric intrusions, the Santa Ana winds, and wildland fires in Southern California, Geophys. Res. Lett., 42, 6091-6097, doi:10.1002/2015GL064964.

Langford, A. O., et al. (2015b), An overview of the 2013 Las Vegas Ozone Study (LVOS): Impact of stratospheric intrusions and long-range transport on surface air quality, Atmos. Environ., 109, 305-322, doi:10.1016/J.Atmosenv.2014.08.040.

Lefohn, A. S., H. Wernli, D. Shadwick, S. Limbach, S. J. Oltmans, and M. Shapiro (2011), The importance of stratospheric-tropospheric transport in affecting surface ozone concentrations in the western and northern tier of the United States, Atmos. Environ., 45, 4845-4857, doi:10.1016/J.Atmosenv.2011.06.014.

Lefohn, A. S., H. Wernli, D. Shadwick, S. J. Oltmans, and M. Shapiro (2012), Quantifying the importance of stratospheric-tropospheric transport on surface ozone concentrations at high- and low-elevation monitoring sites in the United States, Atmos. Environ., 62, 646-656, doi:10.1016/J.Atmosenv.2012.09.004.

Lefohn, A. S., C. Emery, D. Shadwick, H. Wernli, J. Jung, and S. J. Oltmans (2014), Estimates of background surface ozone concentrations in the United States based on model-derived source apportionment, Atmos. Environ., 84, 275-288, doi:10.1016/J.Atmosenv.2013.11.033.

Lin, M. Y., A. M. Fiore, O. R. Cooper, L. W. Horowitz, A. O. Langford, H. Levy, B. J. Johnson, V. Naik, S. J. Oltmans, and C. J. Senff (2012a), Springtime high surface ozone events over the western United States: Quantifying the role of stratospheric intrusions, J. Geophys. Res., 117, D00v22, doi:10.1029/2012JD018151.

Lin, M. Y., et al. (2012b), Transport of Asian ozone pollution into surface air over the western United States in spring, J. Geophys. Res., 117, D00v07, doi:10.1029/2011JD016961.

Lin, M. Y., A. M. Fiore, L. W. Horowitz, A. O. Langford, S. J. Oltmans, D. Tarasick, and H. E. Rieder (2015a), Climate variability modulates western US ozone air quality in spring via deep stratospheric intrusions, Nat. Comm., 6, doi:10.1038/Ncomms8105.

Lin, M. Y., L. W. Horowitz, O. R. Cooper, D. Tarasick, S. Conley, L. T. Iraci, B. Johnson, T. Leblanc, I. Petropavlovskikh, and E. L. Yates (2015b), Revisiting the evidence of increasing springtime ozone mixing ratios in the free troposphere over western North America, Geophys. Res. Lett., 42, 8719-8728, doi:10.1002/2015GL065311.

Lock, A. P., A. R. Brown, M. R. Bush, G. M. Martin, and R. N. B. Smith (2000), A new boundary layer mixing scheme. Part I: Scheme description and single-column model tests, Mon. Weather Rev., 128(9), 3187-3199, doi:10.1175/1520-0493(2000)128<3187:Anblms >2.0.Co;2.

Mesinger, F.and Coauthors (2006), North American Regional Reanalysis, Bull. Am. Meteorol. Soc., 87, 343-360.

Olivier, J. G. J., J. A. Van Aardenne, F. Dentener, L. Ganzeveld, and J. A. H. W. Peters (2005), Recent trends in global greenhouse gas emissions: Regional trends and spatial distribution of key sources, in Non- $\mathrm{CO}_{2}$ Greenhouse Gases (NCGG-4), edited by A. V. Amstel, pp. 325-330, Millpress, Rotterdam, Netherlands.

Pierce, R. B., et al. (2003), Regional Air Quality Modeling System (RAQMS) predictions of the tropospheric ozone budget over East Asia, J. Geophys. Res., 108(D21), 8825, doi:10.1029/2002JD003176.

Pierce, R. B., et al. (2007), Chemical data assimilation estimates of continental US ozone and nitrogen budgets during the Intercontinental Chemical Transport Experiment-North America, J. Geophys. Res., 112, doi:10.1029/2006JD007722.

Prather, M. J., X. Zhu, Q. Tang, J. N. Hsu, and J. L. Neu (2011), An atmospheric chemist in search of the tropopause, J. Geophys. Res., 116, D04306, doi:10.1029/2010JD014939.

Ryerson, T. B., et al. (2013), The 2010 California Research at the Nexus of Air Quality and Climate Change (CalNex) field study, J. Geophys. Res. Atmos., 118, 5830-5866, doi:10.1002/jgrd.50331.

Schuepbach, E., T. D. Davies, and A. C. Massacand (1999), An unusual springtime ozone episode at high elevation in the Swiss Alps: Contributions both from cross-tropopause exchange and from the boundary layer, Atmos. Environ., 33, 1735-1744.

Seidel, D. J., C. O. Ao, and K. Li (2010), Estimating climatological planetary boundary layer heights from radiosonde observations: Comparison of methods and uncertainty analysis, J. Geophys. Res., 115, D16113, doi:10.1029/2009JD013680.

Seidel, D. J., Y. H. Zhang, A. Beljaars, J. C. Golaz, A. R. Jacobson, and B. Medeiros (2012), Climatology of the planetary boundary layer over the continental United States and Europe, J. Geophys. Res., 117, D17106, doi:10.1029/2012JD018143.

Skerlak, B., M. Sprenger, and H. Wernli (2014), A global climatology of stratosphere-troposphere exchange using the ERA-Interim data set from 1979 to 2011, Atmos. Chem. Phys., 14(2), 913-937, doi:10.5194/Acp-14-913-2014.

Sprenger, M., and H. Wernli (2003), A northern hemisphere climatology of cross-tropopause exchange for the ERA15 time period (1979-1993), J. Geophys. Res., 108, doi:10.1029/2002JD002636.

State of Wyoming (2013), Exceptional event demonstration package for the Environmental Protection Agency: Big piney and boulder, Wyoming Ozone Standard Exceedances June 14, 2012, edited, Department of Environmental Quality/Air Quality Division.

Stewart, J. Q., C. D. Whiteman, W. J. Steenburgh, and X. D. Bian (2002), A climatological study of thermally driven wind systems of the US Intermountain West, Bull. Am. Meteorol. Soc., 83(5), 699-708, doi:10.1175/1520-0477(2002)083<0699:Acsotd >2.3.Co;2.

Stohl, A., C. Forster, A. Frank, P. Seibert, and G. Wotawa (2005), Technical note: The Lagrangian particle dispersion model FLEXPART version 6.2, Atmos. Chem. Phys., 5, 2461-2474.

Stohl, A., N. Spichtinger-Rakowsky, P. Bonasoni, H. Feldmann, M. Memmesheimer, H. E. Scheel, T. Trickl, S. Hubener, W. Ringer, and M. Mandl (2000), The influence of stratospheric intrusions on alpine ozone concentrations, Atmos. Environ., 34(9), 1323-1354, doi:10.1016/S13522310(99)00320-9.

Stohl, A., et al. (2003a), Stratosphere-troposphere exchange: A review, and what we have learned from STACCATO, J. Geophys. Res., 108(D12), doi:10.1029/2002JD002490.

Stohl, A., H. Wernli, P. James, M. Bourqui, C. Forster, M. A. Liniger, P. Seibert, and M. Sprenger (2003b), A new perspective of stratospheretroposphere exchange, Bull. Am. Meteorol. Soc., 84, 1565-1573.

Stull, R. B. (1988), An Introduction to Boundary Layer Meterology, Kluwer Acad., Dordrecht, Netherlands.

Trickl, T., H. Feldmann, H. J. Kanter, H. E. Scheel, M. Sprenger, A. Stohl, and H. Wernli (2010), Forecasted deep stratospheric intrusions over central Europe: Case studies and climatologies, Atmos. Chem. Phys., 10, 499-524.

Trickl, T., H. Vogelmann, H. Giehl, H. E. Scheel, M. Sprenger, and A. Stohl (2014), How stratospheric are deep stratospheric intrusions?, Atmos. Chem. Phys., 14(18), 9941-9961, doi:10.5194/Acp-14-9941-2014.

U.S. Environmental Protection Agency (1999), The Benefits and Costs of the Clean Air Act 1990 to 2010Rep. EPA-410-R-99-001, Office of Air and Radiation, Washington, D. C.

U.S. Environmental Protection Agency (2014), Policy assessment for the review of the ozone national ambient air quality standards Rep., Research Triangle Park, North Carolina.

U.S. Environmental Protection Agency (2015), National ambient air quality standards for ozone: Final rule, in EPA-HQ-OAR-2008-0699; FRL9933-18- OAR, edited by U. S. Environmental Protection Agency, Federal Register. 
VanCuren, R. (2015), Transport aloft drives peak ozone in the Mojave desert, Atmos. Environ., 109, 331-341, doi:10.1016/j. atmosenv.2014.09.057.

Viezee, W., W. B. Johnson, and H. B. Singh (1983), Stratospheric ozone in the lower troposphere-II. Assessment of downward flux and ground-level impact, Atmos. Environ., 17, 1979-1993.

Warneck, P. (1988), Chemistry of the Natural Atmosphere, 753 pp, Academic Press, San Diego, Calif.

Wernli, H., and M. Bourqui (2002), A Lagrangian "1-year climatology" of (deep) cross-tropopause exchange in the extratropical Northern Hemisphere, J. Geophys. Res., 107(D1-D2), doi:10.1029/2001JD000812.

Williams, E. J., F. C. Fehsenfeld, B. T. Jobson, W. C. Kuster, P. D. Goldan, J. Stutz, and W. A. McClenny (2006), Comparison of ultraviolet absorbance, chemiluminescence, and DOAS instruments for ambient ozone monitoring, Environ. Sci. Technol., 40, doi:10.1021/es0523542. Zhang, L., D. J. Jacob, X. Yue, N. V. Downey, D. A. Wood, and D. Blewitt (2014), Sources contributing to background surface ozone in the US Intermountain West, Atmos. Chem. Phys., 14(11), 5295-5309, doi:10.5194/acp-14-5295-2014. 